\title{
27. THE IMPACT OF FLUID AND GAS VENTING ON BACTERIAL POPULATIONS AND PROCESSES IN SEDIMENTS FROM THE CASCADIA MARGIN ACCRETIONARY SYSTEM (SITES 888-892) AND THE GEOCHEMICAL CONSEQUENCES ${ }^{1}$
}

\author{
B.A. Cragg, ${ }^{2}$ R.J. Parkes, ${ }^{2}$ J.C. Fry, ${ }^{3}$ A.J. Weightman, ${ }^{3}$ P.A. Rochelle, ${ }^{3}$ J.R. Maxwell, ${ }^{4}$ M. Kastner, ${ }^{5}$ \\ M. Hovland, ${ }^{6}$ M.J. Whiticar, ${ }^{7}$ and J.C. Sample ${ }^{8}$
}

\begin{abstract}
Bacterial populations and activity were quantified at four Ocean Drilling Program Leg 146 sites in the Cascadia Margin accretionary wedge, off the west Canadian/American coast. At two sites the sediments contained gas hydrates: Site 889/890 had a discrete hydrate zone for $\sim 10 \mathrm{~m}$ above the bottom-simulating reflector (BSR) at $225 \mathrm{~m}$ below the sea floor (mbsf), and Site 892 had disseminated hydrate in the top $\sim 20 \mathrm{mbsf}$ and a BSR at $73 \mathrm{mbsf}$. Site 891 had fault zones and discrete zones of active fluid venting. The other site, 888 , was a control site without gas hydrates or substantial fluid venting. Bacterial populations were present at all sites with deepest samples from Site 888 at 564 mbsf. The control Site 888 and the top $90 \mathrm{mbsf}$ of Site $889 / 890$ had bacterial distributions similar to previous sites studied in the Pacific Ocean. In the top $20 \mathrm{~m}$ of Site 892 , however, bacterial populations were much lower than in the other two sites; they may have been inhibited by the high concentrations of hydrogen sulfide within the hydrate zone. Below this depth, bacterial populations increased to concentrations consistent with other sites, apart from local decreases in Hole $892 \mathrm{~A}$ associated with thermally generated aromatic hydrocarbons, which might be toxic to a portion of the bacterial community. Near-surface bacterial populations at $891 \mathrm{~A}$ were $\sim 4.5$ times higher than expected, probably reflecting fluid venting near this site. Below about $50 \mathrm{mbsf}$ at this site (Hole 891B), bacterial populations were also elevated and peaks corresponded to geochemical anomalies resulting from fluid venting.

Bacterial processes generally decreased with increasing depth at the control site, which was dominated by sulfate reduction, and rates of methane oxidation in the top $90 \mathrm{~m}$ were low, ranging from 0.002 to $0.033 \mathrm{nmol} / \mathrm{cm}^{3} / \mathrm{d}$. Fluid and gas venting have a marked effect on deep bacterial processes at Sites 891 and 889/890: in contrast to the control site, maximum bacterial activities occur and bacterial populations are elevated at depth (sub-200 mbsf), reflecting marked increases in methane oxidation. At Site $889 / 890$, bacterial populations and activity were stimulated in the discrete hydrate zone. Methane oxidation rates increased in the middle of this zone to $134.5 \mathrm{nmol} / \mathrm{cm}^{3} / \mathrm{d}$, and this resulted in a significant increase in the total bacterial population. The anaerobic process(es) responsible for methane oxidation remain unclear, but fluid flux into accretionary wedge sediments may be an important process in providing electron acceptors to maintain these high rates of methane oxidation. Variation in bacterial profiles between cores at the same site ( 891 and 892 ), only a few meters apart, closely reflect spatial heterogeneity in geochemistry and fluid expulsion in these accretionary sediments, demonstrating that bacterial processes are a sensitive index for the fluid and gas venting that may drive many of the geochemical changes.
\end{abstract}

\section{INTRODUCTION}

Accretionary prisms are areas of intense tectonic activity that result in the expulsion of large quantities of fluids and volatile components as the subducting oceanic sediments are compressed. This expulsion influences ocean chemistry and also the concentration of the greenhouse gas methane. The presence of dense biological communities at the sediment surface at some sites, coupled with extensive carbonate deposits (Moore et al., 1991; Kulm et al., 1986), clearly indicate that biological, and in particular microbiological, factors have

'Carson, B., Westbrook, G.K., Musgrave, R.J., and Suess, E. (Eds.), 1995. Proc. ODP, Sci. Results, 146 (Pt. 1): College Station, TX (Ocean Drilling Program).

${ }^{2}$ Department of Geology, University of Bristol, Bristol BS8 IRJ, United Kingdom.

${ }^{3}$ School of Pure and Applied Biology, University of Wales College of Cardiff, P.O. Box 915, Cardiff CF1 3TL, United Kingdom. dom.

${ }^{4}$ Department of Chemistry, University of Bristol, Bristol BS8 1RJ, United King-

scripps Institute of Oceanography, Geological Research Division A-012, La Jolla, CA 92093, U.S.A.

${ }^{6}$ Statoil, P.O. Box 300, N-4001 Stavanger, Norway.

'SEOS, University of Victoria, P.O. Box 1700, Victoria, British Columbia V8N IYU, Canada.

${ }^{8}$ Department of Geological Sciences, California State University, 1250 Bellflower Blvd., Long Beach, CA 90840 , U.S.A. a profound effect on chemical and gaseous fluxes from these sediments. In addition, the microbiological production of carbonate cements, both at the sediment surface and subsurface ( $<200 \mathrm{mbsf})$, may have a direct effect on rates and patterns of venting (Carson et al., 1991). As cementation inevitably leads to a reduction in porosity and permeability, continued venting is probably associated with repeated faulting and development of a fracture permeability. Microbial involvement in these dynamic sediments is largely assumed from indirect geochemical data (e.g., Suess and Whiticar, 1989), and more detailed direct microbial measurements are now required in order to increase our understanding of diagenetic processes and the control of chemical fluxes from these sites, especially methane.

Cascadia Margin is a subduction zone in the eastern Pacific Ocean (Fig. 1) with a thick layer (up to $3.5 \mathrm{~km}$ ) of turbidites and hemipelagic deposits, which on compression produces intense fluid and volatiles 'expulsion (Westbrook, Carson, Musgrave, et al., 1994). Methane release can be diffuse or focused along faults, and at certain sites it is concentrated prior to slow release within hydrates, as inferred from bottom simulating reflectance (BSR). $\delta^{13} \mathrm{C}$ measurements of biogenic carbonates suggest that the venting methane is the residue of a previously produced biogenic pool ( $-70 \%$ to $-90 \%$ Pee Dee belemnite or PDB) supplemented by carbon dioxide from microbial degradation of organic matter $(-20 \%$ PDB) producing the observed carbonate values $(-35 \%$ to $-63 \%$ PDB; Suess and Whiticar, 1989). Different 


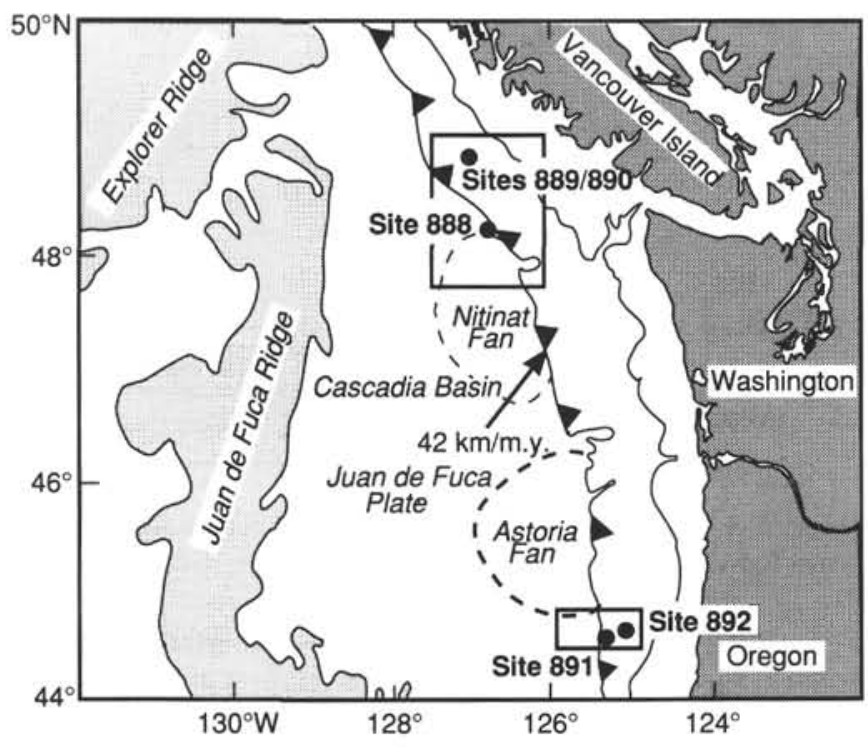

Figure 1. Location map of the Cascadia Margin, showing the convergent plate motion, major physiographic features in the Cascadia Basin (overlying the Juan de Fuca Plate), the position of the continental margin, and the position of drilling sites off Vancouver Island and Oregon. (From Westbrook, Carson, Musgrave, et al., 1994).

styles of carbonate cementation, with different isotopic signatures, appear to be produced from vent fluids of different origin (e.g., source or depth), and such an effect is likely to be bacterially mediated. There is also a thermogenic component to the venting fluids, including methane, higher hydrocarbons, and aromatic hydrocarbons (Westbrook, Carson, Musgrave, et al., 1994).

As much as $30 \%$ of the total carbon dioxide in the pore water within the Cascadia Margin sediment is thought to be produced from methane oxidation, with a significant contribution from anaerobic methane oxidation, probably by sulfate-reducing bacteria (Kulm and Suess, 1990; Suess and Whiticar, 1989). However, despite increasing environmental evidence (Schulz et al., 1994; Masuzawa et al., 1992; King, 1992; Helgeson et al., 1991; Jørgensen et al., 1990; Iversen and Jørgensen, 1985; Alperin and Reeburgh, 1985; Zehnder and Brock, 1980; Kosiur and Warford, 1979), there is some speculation regarding anaerobic methane oxidation by sulfate-reducing bacteria, as the causative bacteria have not yet been isolated (Widdel, 1988; King, 1992). In other marine sediments, rates of anaerobic methane oxidation can be up to four times the upward methane flux (Iversen and Jørgensen, 1985). These and other diagenetic processes should be clearly reflected in distributional changes in bacterial activities, biomass, and the composition of the active bacterial population, even in deep sediment layers, as bacteria have been shown to be active to at least 520 meters below seafloor (mbsf; Parkes et al., in press, 1994, 1990; Cragg et al., 1992b) in the Pacific Ocean. This is the first investigation of deep bacterial processes in subduction zone sediments.

\section{MATERIALS AND METHODS}

\section{Site Description}

Samples for bacterial analysis were taken from cores at four sites on the Cascadia Margin (Fig. 1). Two sites were off Vancouver Island: Site $888\left(48^{\circ} 10.009^{\prime} \mathrm{N}, 126^{\circ} 39.794^{\prime} \mathrm{W}\right)$, and Site $890 / 889$ $\left(48^{\circ} 39.750^{\prime} \mathrm{N}, 126^{\circ} 52.890^{\prime} \mathrm{E}\right.$ and $\left.48^{\circ} 41.958^{\prime} \mathrm{N}, 126^{\circ} 52.098^{\prime} \mathrm{E}\right)$, and two sites were off central Oregon: Site $891 \quad\left(44^{\circ} 38.648^{\prime} \mathrm{N}\right.$, $\left.125^{\circ} 19.55^{\prime} \mathrm{W}\right)$, and Site $892\left(44^{\circ} 40.440^{\prime} \mathrm{N}, 125^{\circ} 7.140^{\prime} \mathrm{E}\right)$.
Site 888 was $7 \mathrm{~km}$ seaward of the toe of the accretionary wedge and provided a control site without gas hydrates but with the same sediment types, age, and physical properties as the other sites.

Upper core retrieval at Site 889 was prevented by proximity to a munitions dump. Near-surface sediments were obtained from Site 890 (surface to $47.8 \mathrm{mbsf}$ cored), which was laterally separated by approximately $4 \mathrm{~km}$ from Site 889 ( 20 to $345.8 \mathrm{mbsf}$ cored). They were, however, treated as the same site for microbiological purposes and the overlap of $27 \mathrm{~m}$ was to ensure that the data could be linked. At Site 889 the BSR was initially estimated to be at approximately 270 mbsf (Westbrook, Carson, Musgrave, et al., 1994), but with consideration of additional data this was subsequently adjusted to 225 mbsf. The theoretical hydrate stability zone at the Cascadia Margin has been estimated to be from seafloor to $250-300 \mathrm{mbsf}$, and velocity data suggest that the hydrate is concentrated near the BSR in a layer probably less than $25 \mathrm{~m}$ thick (Hyndman and Davis, 1992). This is an area of diffuse pore-fluid expulsion with vertical fluid flow estimated at $8 \times 10^{-10}$ to $8 \times 10^{-11} \mathrm{~m} / \mathrm{s}$ (Bekins and Dreiss, 1992; Davis et al., 1990 ) and a source depth of $1400 \mathrm{~m}$ for the fluid now being expelled (Hyndman and Davis, 1992).

Site 891 (surface to 472 mbsf cored) is on the westernmost ridge of the accretionary wedge at the foot of the Oregon continental margin (Westbrook, Carson, Musgrave, et al., 1994). There was a thrust fault at 375 mbsf and part of the purpose in coring this site was to determine if there was fluid advection along the thrust fault. Cores from Hole $891 \mathrm{~A}$ were stroked incompletely and coring ceased at $9.5 \mathrm{mbsf}$. Remaining samples were taken from Hole 891B, approximately $30 \mathrm{~m}$ distant.

At Site 892 (surface to $167 \mathrm{mbsf}$ cored) a well-developed BSR exists at approximately $73 \mathrm{mbsf}$, which is deflected toward the surface along a fault zone (Westbrook, Carson, Musgrave, et al., 1994). In contrast to Vancouver Island, at the Oregon continental margin there is active pore fluid venting along fractures in disrupted sediments. This venting is associated with sediment surface communities of clams and tube-worms (Lewis and Cochrane, 1990; Suess et al., 1985). Estimates of discharge rates at venting sites were $100-1765 \mathrm{~L} /$ $\mathrm{m}^{2} / \mathrm{d}$, implying an advective subsurface flow of $3 \times 10^{-6}$ to $3 \times 10^{-5}$ $\mathrm{m} / \mathrm{s}$ (Linke et al., 1994; Carson et al., 1990). As this rate is several orders of magnitude greater than the predicted average rate of fluid expulsion of $1 \times 10^{-11}$ to $3 \times 10^{12} \mathrm{~m} / \mathrm{s}$, Carson et al. (1991) suggest that either there is substantial subsurface lateral fluid movement or that vents are short-term features with non-steady flow.

\section{Shipboard Sampling Handling}

All 30 samples were $20 \times 50$-cm whole round cores (WRC) and were obtained from Sites 888 ( 9 samples, 0.05-398.2 mbsf), 890 (6 samples, $0.1-10.3$ mbsf), 889 ( 5 samples, $80.0-234.3$ mbsf), and 891 (10 samples, 0.1-368 mbsf) for measurement of bacterial activity and estimation of bacterial numbers. The samples were removed from the middle of $1.5-\mathrm{m}$ core sections using a specially constructed sterile cutting rig (Cragg et al., 1992b). The cut ends of the WRC were flamed and capped with sterile (gamma irradiated) core end caps while gassing with sterile oxygen-free-nitrogen (OFN). They were stored in gas-tight anaerobic bags (Cragg et al., 1992a) in the ships cold-room at $4^{\circ} \mathrm{C}$ for approximately two weeks and transported back to the laboratory in insulated trunks containing wet ice and ice-packs. During transportation the samples remained cold. On arrival at the laboratory they were stored in a constant-temperature room at $4^{\circ} \mathrm{C}$ for two to three weeks until preparations for sediment handling had been completed.

For direct bacterial enumeration additional $1-\mathrm{cm}^{3}$ sediment samples were removed from core sections between 19.5 and $355.5 \mathrm{mbsf}$ at Site 888 ( 7 samples), between 0 and 44.3 mbsf at Site 890 (5 samples), between 23 and 338 mbsf at Site 889 ( 19 samples), between 2.9 and 465 mbsf at Site 891 ( 23 samples), and between 0 and 167 mbsf 
at Site 892 ( 58 samples). Immediately after a core was cut into 1.5-m sections on the catwalk, a thin layer of sediment was removed from the section end using a sterile scalpel to expose an uncontaminated surface. The $1-\mathrm{cm}^{3}$ sample was then taken using a sterile (autoclaved) $5-\mathrm{mL}$ syringe from which the luer end had been removed. The sample was ejected directly into a tared serum vial containing $9 \mathrm{~mL}$ of filtersterilized $(0.2 \mu \mathrm{m}) 4 \%$ formaldehyde in artificial seawater. The nearsurface $1-\mathrm{cm}^{3}$ sediment sample was taken from the loose slurry present at the top of the first core using a sterile $5 \mathrm{~mL}$ syringe. Gas hydrates were encountered in the upper $20 \mathrm{~m}$ of Site 892, and five samples of hydrate were taken using sterile $5-\mathrm{mL}$ syringes. The samples were immediately ejected into vials of formaldehyde as described above and then a sterile needle was temporarily inserted through the butyl rubber crimp top to allow release of the evolved methane as the hydrate decayed.

Headspace methane and carbon dioxide data and interstitial water chemistry data were obtained from standard ODP shipboard analyses (Westbrook, Carson, Musgrave, et al., 1994).

\section{Laboratory Sample Handling}

\section{Whole-Round Cores}

Initial handling and subsampling of sediments was aseptic and anaerobic, according to Parkes et al. (in press, 1994). Syringe subcores were removed for activity measurements (seven $5-\mathrm{cm}^{3}$ subcores per WRC for each of sulfate reduction, methanogenesis, and methane oxidation), Most Probable Number (MPN) viable counts (one $5-\mathrm{cm}^{3}$ subcore per WRC for nitrate- and sulfate-reducing bacteria, and fermentative heterotrophic bacterial enumeration), and direct bacterial counts (two $1-\mathrm{cm}^{3}$ subcore per WRC separately fixed in formaldehyde as described above).

\section{Potential Activity Measurements}

After equilibration of subcores overnight in anaerobic bags, three isotopes were separately injected into different subcores using a Hamilton microsyringe and a specially designed injection rig (Parkes et al., in press), allowing an even distribution of the selected isotope along the center line of the subcore. Each group of seven subcores per isotope was divided into one time-zero control and two subcores each in one of three different incubation periods. Subcores for the timezero control were prechilled at $\left(4^{\circ} \mathrm{C}\right)$, injected, immediately frozen in anaerobic bags at $-20^{\circ} \mathrm{C}$, and stored. Incubated syringes were sealed in anaerobic bags and incubated at $7^{\circ} \mathrm{C}$ (approximate mean downhole temperature for all of our samples; Site $8881^{\circ}-28^{\circ} \mathrm{C}$, Site $889 / 890$ $3^{\circ}-13^{\circ} \mathrm{C}$, Site $8912^{\circ}-6^{\circ} \mathrm{C}$ ) for varying periods (Table 1). Incubation was terminated by freezing at $-20^{\circ} \mathrm{C}$ and subcores were stored at this temperature until analysis.

All isotopes were obtained from Amersham International (Amersham, U.K.). The ${ }^{14} \mathrm{C}$-bicarbonate and ${ }^{35} \mathrm{~S}$-sulfate were diluted with autoclaved distilled water which had been cooled under oxygen-freenitrogen $(\mathrm{OFN})$, filter sterilized $(0.2 \mu \mathrm{m})$, and stored until use in glass vials at $4{ }^{\circ} \mathrm{C}$ and $-20^{\circ} \mathrm{C}$, respectively. ${ }^{14} \mathrm{C}$-methane $(500 \mu \mathrm{L})$ was removed from an adapted break-seal ampoule using a gas syringe and injected through a Mininert valve and septum (Phase Separation, Chester, U.K.) into a sterile adapted serum vial of approximately 8 $\mathrm{mL}$, completely filled with $0.2 \mu \mathrm{m}$ filter sterilized deoxygenated water. Removal of methane solution under pressure, for sample injection, was performed using a gas "Pressure-Lok" syringe (Phase Separation, Chester, U.K.), accompanied by gravity-fed injection of mercury through a rubber septum at the base of the vial to maintain vial pressure and to ensure that the methane remained in solution. Injections into the syringe subcores were ${ }^{35} \mathrm{SO}_{4} 7.2 \mu \mathrm{L}=3.6 \mu \mathrm{Ci}$ for sulfate reduction; $\mathrm{H}^{14} \mathrm{CO}_{3} 7.2 \mu \mathrm{L}=4.8 \mu \mathrm{Ci}$ for methanogenesis; ${ }^{14} \mathrm{CH}_{4}$ $30 \mu \mathrm{L}=0.01 \mu \mathrm{Ci}$ for methane oxidation.

Rates of sulfate reduction were determined from the proportion of ${ }^{35} \mathrm{~S}$-labeled sulfide produced. Sulfide distillation and radioactive
Table 1. Incubation periods for potential activity measurements.

\begin{tabular}{|c|c|c|c|}
\hline \multirow{2}{*}{$\begin{array}{l}\text { Sample depth } \\
\text { (mbsf) }\end{array}$} & \multicolumn{3}{|c|}{ Incubation period (days) } \\
\hline & Time 1 & Time 2 & Time 3 \\
\hline \multicolumn{4}{|l|}{$146-888$} \\
\hline 0.30 & 1.5 & 7.5 & 18.1 \\
\hline 0.83 & 1.5 & 7.5 & 18.1 \\
\hline 1.36 & 1.7 & 7.5 & 18.1 \\
\hline 1.89 & 1.7 & 7.5 & 18.1 \\
\hline 3.75 & 4.7 & 18.0 & 30.0 \\
\hline 10.25 & 4.7 & 18.0 & 30.0 \\
\hline 77,72 & 4.7 & 18.0 & 30.0 \\
\hline 93.57 & 4.7 & 18.0 & 30.0 \\
\hline 397.92 & 7.5 & 30.0 & 52.0 \\
\hline \multicolumn{4}{|l|}{$146-889 / 890$} \\
\hline 0.35 & 0.8 & 1.6 & 2.3 \\
\hline 0.90 & 0.8 & 1.6 & 2.3 \\
\hline 1.68 & 0.8 & 1.6 & 2.3 \\
\hline 4.17 & 0.8 & 1.7 & 2.1 \\
\hline 9.15 & 1.7 & 7.7 & 18.1 \\
\hline 10.55 & 1.7 & 7.7 & 18.1 \\
\hline 80.25 & 4.4 & 18.0 & 30.0 \\
\hline 143.24 & 4.4 & 18.0 & 30.0 \\
\hline 198.55 & 7.6 & 30.0 & 52.0 \\
\hline 222.33 & 7.6 & 30.7 & 52.0 \\
\hline 234.45 & 7.6 & 30.7 & 52.0 \\
\hline \multicolumn{4}{|l|}{$146-891$} \\
\hline 0.34 & 0.7 & 1.6 & 2.3 \\
\hline 0.89 & 1.6 & 7.5 & 38.2 \\
\hline 1.42 & 1.6 & 7.5 & 38.2 \\
\hline 1.95 & 1.6 & 13.0 & 39.0 \\
\hline 3.75 & 1.6 & 13.0 & 39.0 \\
\hline 6.93 & 1.6 & 13.0 & 39.0 \\
\hline 163.80 & 4.6 & 18.0 & 31.2 \\
\hline 238.30 & 4.6 & 18.0 & 31.22 \\
\hline 88.80 & 7.7 & 31.1 & 52.0 \\
\hline 367.45 & 7.7 & 31.1 & 52.0 \\
\hline
\end{tabular}

Notes: Each sample was split into 3 subsamples and incubated for different time periods (Times 1-3) given above. Data presented in "Results" (this chapter) are averages of data obtained from these three incubation periods.

counting was as described by Fossing and Jørgensen (1989). Methanogenesis was estimated from the amount of ${ }^{14} \mathrm{CH}_{4}$ produced. This was oxidized to ${ }^{14} \mathrm{CO}_{2}$ and counted by liquid scintillation as described in Cragg et al. (1990). Methane oxidation rates were obtained from the amount of ${ }^{14} \mathrm{CO}_{2}$ and ${ }^{14} \mathrm{C}$-organic carbon produced. Syringe subcores were ejected into $30-\mathrm{mL}$ serum vials containing $14 \mathrm{~mL}$ of 0.1 $\mathrm{mol} / \mathrm{L} \mathrm{NaOH}$. The vial was crimp sealed, vigorously shaken to disperse the sediment, connected to a flushing system $(60 \mathrm{~mL} / \mathrm{min}$ OFN for $30 \mathrm{~min}$ ), and the ${ }^{14} \mathrm{CH}_{4}$ content of the vial measured after oxidation to ${ }^{14} \mathrm{CO}_{2}$ (Cragg et al., 1990). The vial was then connected to a different flushing system consisting of a simple stainless steel tube with an acid trap $(1.0 \mathrm{~mol} / \mathrm{L} \mathrm{HCl})$ to intercept aerosol droplets. The vial contents were acidified $(2 \mathrm{~mL}$ of $1.0 \mathrm{~mol} / \mathrm{L} \mathrm{HCl})$ and stirred. The headspace was flushed ( $40 \mathrm{~mL} / \mathrm{min}$ OFN for $30 \mathrm{~min}$ ) through three scintillation vials containing a scintillant including B-phenylethlyamine to trap evolved ${ }^{14} \mathrm{CO}_{2}$ (Cragg et al., 1990). Subsequently, a portion of the remaining sediment was added to a different scintillation fluid (Instagel; Canberra-Packard, U.K.) and activity determined to measure incorporation of ${ }^{14} \mathrm{C}$ into organic compounds. Time-zero control results were deducted from experimental samples before rate calculation.

\section{Counts of Viable Bacteria}

An MPN technique (Colwell, 1979) was used to estimate numbers of viable fermentative heterotrophs and nitrate- and sulfate-reducing bacteria. Nitrate reducers were interpreted as reflecting general respiratory anaerobic heterotrophs, as nitrate is effectively zero in these reducing sediments. This procedure involved nine dilution levels from the original sediment, descending serially in quadruplicate 1:5 dilutions. All MPN enrichments were performed in 7-mL hypovials of anaerobic media sealed with butyl rubber septa and aluminum crimp tops (Phase Separation, Chester, U.K.). Full details of vial and 
media preparation together with the media dispensing system and sediment handling procedures are described in Parkes et al. (in press). Presumptive nitrate reducers were detected by the effects of acid production on the indicator bromothymol blue contained in the medium. Viable fermentative heterotrophs were estimated by direct microscopic counting under phase contrast. Sulphate-reducing bacteria were determined by black precipitation of iron monosulphide. Viable counts and confidence limits were calculated according to Hurley and Roscoe (1983).

\section{Direct Microscopic Enumeration}

Total bacterial numbers were estimated using Acridine Orange staining and microscopic observations based on the general recommendations of Fry (1988) with minor modification. The formaldehyde-fixed samples were vortex mixed, and between 5 and $10 \mu \mathrm{L}$ added to $10 \mathrm{~mL}$ of $2 \% 0.1 \mu \mathrm{m}$ filter-sterilized formaldehyde. Acridine Orange $(50 \mu \mathrm{L})$ was added to give a final concentration of $5 \mathrm{mg} /$ $\mathrm{cm}^{3}$. After $3 \mathrm{~min}$ the solution was filtered through a $25-\mathrm{mm}$ Nucleopore black polycarbonate membrane (Appleton Woods, Birmingham, U.K.) of $0.2-\mu \mathrm{m}$ pore size. The filter was rinsed with $10 \mathrm{~mL}$ of $2 \%$ filter-sterilized formaldehyde and mounted in a minimum amount of paraffin oil under a cover slip. Triplicate membranes were prepared from each sample.

Mounted membrane filters were viewed under incident illumination with a Zeiss Axioskop microscope fitted with a 50-W mercuryvapor lamp, a wide-band interference set for blue excitation, a 100x (numerical aperture $=1.3$ ) Plan Neofluar objective lens, and 10x eyepieces. Bacterially shaped green or red fluorescing objects were counted. Cells on or off particles were counted separately, and the numbers of those on particles were doubled in the final calculations to account for cells hidden from view by particles (Goulder, 1977). Dividing cells (those with a clear invagination) and divided cells (pairs of cells of identical morphology) were also counted. A minimum of 200 fields of view were counted on each membrane. Where replicate $\log _{10}$ counts differed by more than $0.5 \log _{10}$ units, a fourth membrane was prepared. The detection limit was calculated to be 1 $\times 10^{5} \mathrm{cells} / \mathrm{cm}^{3}$ (Cragg, 1994).

The five samples from Site 892 containing hydrate were not "clean," as they included some associated sediment particles. After bacterial enumeration, the contents of the vials were filtered through tared GF/C filter papers (previously washed and dried at $105^{\circ} \mathrm{C}$ ), rinsed with deionized water, and dried to constant weight at $105^{\circ} \mathrm{C}$, to determine the amount of sediment present.

\section{RESULTS}

\section{Site 888}

\section{Bacterial Populations}

Total bacterial populations are high at the near-surface $(5.32 \times$ $10^{8} / \mathrm{cm}^{3}$ at $0.075 \mathrm{mbsf}$ ) and then decrease with depth (Fig. 2). The bacterial population at 355 mbsf represents a $>99 \%$ decrease of the near-surface population, but, at $1.2 \times 10^{6} \mathrm{~cm}^{3}$, it remains substantial. There are some increases in bacterial populations above this decreasing trend, notably between 20-70 mbsf and 90-294 mbsf. These increases coincide with zones of elevated organic carbon (Westbrook, Carson, Musgrave, et al., 1994), and overall there is a significant relationship between the total bacterial population and organic carbon concentrations $(R=0.528 ; n=18 ; P<0.05)$. Dividing cells were present in all samples representing, on average, $11 \%$ of the total bacterial population.

Viable bacteria reflect the depth profile of the total bacterial population, with high near-surface populations that decrease within the top 1 mbsf (Fig. 2). Fermentative heterotrophic bacteria slowly increase to $10 \mathrm{mbsf}$ and then decrease with depth. There is a small in- crease in this bacterial population at about $90 \mathrm{mbsf}$, which coincides with a marked increase in nitrate-reducing bacteria. The depth distribution of sulfate-reducing bacteria is similar to the other bacteria, except there is a population increase between about 0.6 and $3 \mathrm{mbsf}$ but no increase around $90 \mathrm{~m}$.

\section{Bacterial Activity}

Rates of sulfate reduction are high near the surface $(88.5 \mathrm{nmol} /$ $\mathrm{cm}^{3} / \mathrm{d}$ ) and decrease rapidly with increasing depth to $10 \mathrm{mbsf}$ (Fig. 2). This is consistent with a rapid decrease in near-surface organic carbon from 0.99 wt $\%$ to 0.13 wt \% at 4 mbsf (Westbrook, Carson, Musgrave, et al., 1994). Below this depth, organic carbon fluctuates at about $0.4 \mathrm{wt} \%$ and is considered to be relatively refractory material of terrigenous origin (Westbrook, Carson, Musgrave, et al., 1994). At $78 \mathrm{mbsf}$ there is a small increase in sulfate reduction rates, which coincides with increases in some of the viable bacterial population (Fig. 2). Rates of methanogenesis had a similar depth distribution (Fig. 2), but rates near the sediment surface were 4 orders of magnitude lower than sulfate reduction rates $\left(0.006 \mathrm{nmol} / \mathrm{cm}^{3} / \mathrm{d}\right)$ and then decreased with depth.

In contrast, methane oxidation rates were low near the sediment surface $\left(0.057 \mathrm{nmol} / \mathrm{cm}^{3} / \mathrm{d}\right)$ and remained low until approximately 90 mbsf (Fig. 2). At greater depths methane oxidation increased, further reflecting the increase in methane gas concentrations (Fig.2), while other activities remained low or were decreasing.

\section{Geochemistry}

Although the shallowest depth for which sulfate data is available is 2.9 mbsf (Fig. 2; Westbrook, Carson, Musgrave, et al., 1994), it is clear that sulfate concentrations would have been decreasing in the near-surface sediments where sulfate reduction rates were high. Although rates of sulfate reduction are very low below $10 \mathrm{mbsf}$, activity is sufficient to result in accumulation of Total Reduced Inorganic Sulphide (TRIS) and removal of dissolved sulfate (Fig. 2). Overall, the geochemistry is dominated by sulfate reduction resulting in increased alkalinity and ammonium concentrations, until sulfate-reducing bacteria become sulfate limited (Westbrook, Carson, Musgrave, et al., 1994). The presence of very low concentrations of methane (0$5 \mathrm{ppmv}$ ), even in the sulfate reduction zone, is consistent with the presence of low rates of methanogenesis and methane oxidation (Fig. 2). Surprisingly, there is a local sulfate depletion between 87 and 113 mbsf, which coincides with an increase in methane and carbon dioxide, as well as increases in bacterial activity and some viable bacterial populations (Fig. 2).

\section{Site $\mathbf{8 9 0 / 8 8 9}$}

\section{Bacterial Populations}

Total bacterial populations are high near the surface $\left(2.63 \times 10^{8} /\right.$ $\mathrm{cm}^{3}$; Fig. 3) and overall, decrease with depth to about $217 \mathrm{mbsf}$. Here, the trend is reversed and there is a zone in which bacterial numbers significantly increase (between $\mathrm{p}<0.025$ and $\mathrm{p}<0.005$ ) at 5 of the 6 sediment layers sampled between 222 and 234 mbsf. The greatest increase of $\times 10$ was recorded at 226.7 mbsf. A similar trend occurs in the numbers of dividing cells.

These bacterial distributions are repeated but are more exaggerated in the distribution of viable bacterial populations (Fig. 3). Fermentative and sulfate-reducing bacteria were present at similarly high concentrations in the near-surface sediments $\left(2.7 \times 10^{4}\right.$ and $1.8 \times$ $10^{4} / \mathrm{cm}^{3}$, respectively) and then decreased considerably in deeper sediments. SRB decreased rapidly, reaching zero around $10 \mathrm{mbsf}$, while fermentative bacteria, after a decrease in the top $1 \mathrm{~m}(98 \%)$ remained relatively constant to $10 \mathrm{mbsf}$, followed by a gradual decrease to 143 mbsf. Nitrate-reducing bacteria tended to be present at low concentrations in the top 140 mbsf. Surprisingly, between about 200 and 230 
A

B

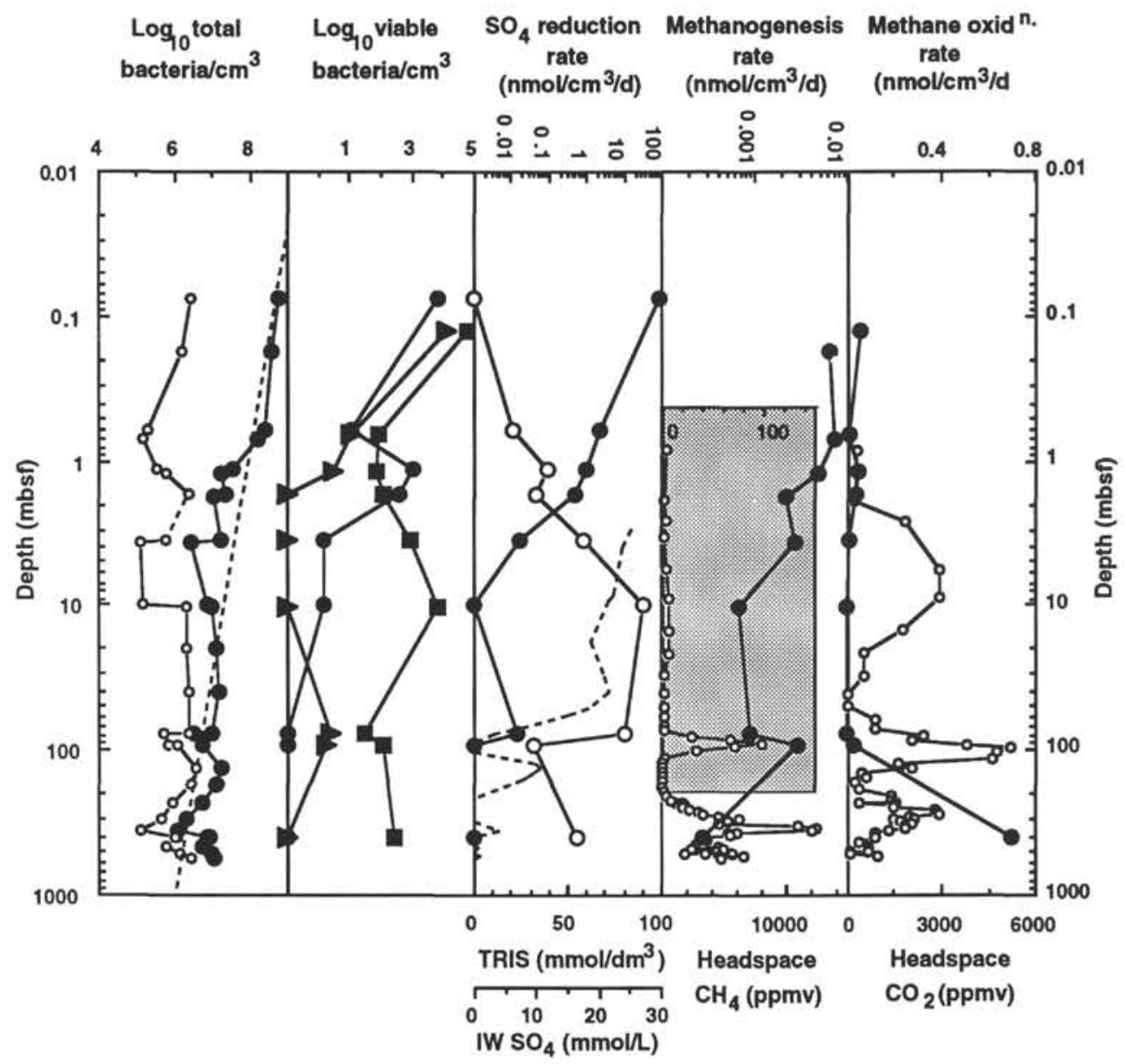

Figure 2. Hole 888B bacterial and geochemical depth distributions. A. Total bacteria (closed circles) and dividing/divided cell numbers (open circles). Dashed lines between data points represent a count below the detection limit. The slanting heavy dashed line is a general regression line of bacterial numbers vs. depth derived from other Pacific sites (Parkes et al., 1994). B. Sulfate-reducing bacteria (closed circles), fermentative heterotrophs (closed squares), and nitrate-reducing bacteria (closed triangles). C. Potential bacterial sulfate reduction rate (closed circles), TRIS (open circles), and pore-water sulfate (dashed line). D. Potential bacterial methanogenesis rate (closed circles), and headspace methane (smoothed using a 3-point moving average, open circles), shaded inset is a scaleexpanded section of the headspace methane data. E. Potential bacterial methane oxidation rate (closed circles), and headspace carbon dioxide (smoothed using a 3-point moving average; open circles).

mbsf there was a marked increase in viable bacteria, which coincided with the zone of increased total bacterial population.

\section{Bacterial activity}

Sulphate reduction was the dominant anaerobic process in the top $\sim 3 \mathrm{~m}$. Rates decreased rapidly with depth (Fig. 3) from a maximum near-surface value of 6.9 to $0.02 \mathrm{nmol} / \mathrm{cm}^{3} / \mathrm{d}$ at $3.9 \mathrm{mbsf}$. This correlated significantly $(R=0.98 ; n=8 ; P<0.002)$ with the decrease in the sulfate-reducing bacterial viable count, and parallels the decrease in pore-water sulfate $(R=0.98 ; n=8 ; P<0.002)$. Methanogenesis rates were low $\left(0.001 \mathrm{nmol} / \mathrm{cm}^{3} / \mathrm{d}\right.$, over 3 orders of magnitude lower than sulfate reduction rates) near the sediment surface, where sulfate reduction was maximal, and increased as sulfate reduction decreased (Fig. 3). By 9 mbsf methanogenesis was slightly greater than sulfate reduction, then both decreased to $143 \mathrm{mbsf}$. In the zone of elevated bacterial population, both sulfate reduction and methanogenesis increase ( $\times 12$ and $\times 51$, respectively), producing clear subsurface maximums in bacterial activity between 198 and 234 mbsf (Fig. 3).

The depth distribution of methane oxidation, to about $200 \mathrm{mbsf}$, is approximately the reverse of the other activity measurements. It is low near the sediment surface $\left(0.124 \mathrm{nmol} / \mathrm{cm}^{3} / \mathrm{d}\right)$, increases considerably in the top $4 \mathrm{mbsf}(\times 150)$, then remains relatively constant to about 200 mbsf (Fig. 3). Below this depth, however, rates of methane oxidation peak to maximum values $\left(135 \mathrm{nmol} / \mathrm{cm}^{3} / \mathrm{d}\right)$, coinciding with the zone of increase in other bacterial activities. Within this zone of elevated bacterial activity (198-234 mbsf), the peaks in individual activities actually occur at different depths, with sulfate reduction peaking at $198 \mathrm{mbsf}$, methane oxidation at $222 \mathrm{mbsf}$, and methanogenesis at 234 mbsf (Fig. 4). A depth difference in the peak of different viable groups of anaerobic bacteria also occurs within this zone (Fig. 4).

\section{Geochemistry}

Consistent with high sulfate reduction rates in the top $10 \mathrm{~m}$ sulfate was rapidly removed in this interval (Fig. 3). The relationship between sulfate reduction rates and the amount of sulfide produced by this process preserved in the sediment TRIS, was, however, more complicated. To a depth of about $80 \mathrm{mbsf}$, there was a negative relationship between rates of sulfate reduction and TRIS, indicating that even in these anoxic sediments a considerable amount of the sulfide 
A

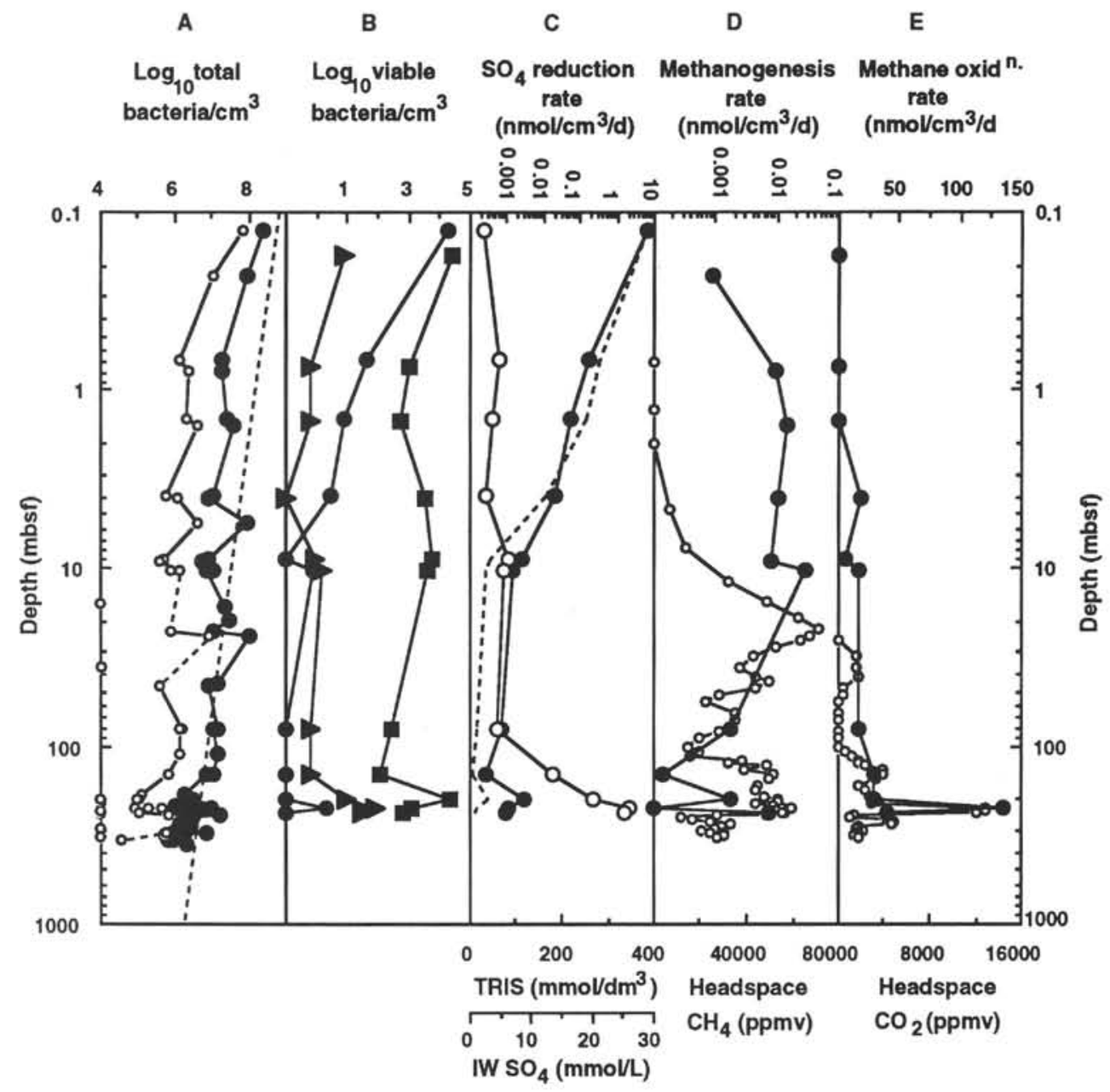

Figure 3. Holes $889 \mathrm{~A} / 890 \mathrm{~B}$ bacterial and geochemical depth distributions. A. Total bacteria (closed circles) and dividing/divided cell numbers (open circles). Dashed lines between data points represent a count below the detection limit. The slanting heavy dashed line is a general regression line of bacterial numbers vs. depth derived from other Pacific sites (Parkes et al., 1994). B. Sulfate-reducing bacteria (closed circles), fermentative heterotrophs (closed squares), and nitratereducing bacteria (closed triangles). C. Potential bacterial sulfate reduction rate (closed circles), TRIS (open circles), and pore-water sulfate (dashed line). D. Potential bacterial methanogenesis rate (closed circles), and headspace methane (smoothed using a 3-point moving average, open circles). E. Potential bacterial methane oxidation rate (closed circles), and headspace carbon dioxide (smoothed using a 3-point moving average, open circles).

produced was oxidized, particularly over the top $10 \mathrm{~m}$ (Fig. 3). Below this depth there was a positive relationship between rates of sulfate reduction and TRIS, indicating that more of the sulfide produced was preserved in the sediment, presumably as sulfide minerals, including pyrite. A similar relationship between sulfate reduction rates and total reduced sulfide has been observed in other deep sediment layers (Cragg et al., 1992b). TRIS concentrations increased markedly in the zone of the sub-surface sulfate reduction maximum, which confirms that the elevated sulfate reduction rates are a reflection of a deep in situ zone of sulfate reduction.

Despite methanogenesis in the top $1 \mathrm{~m}$ (Fig. 3) methane was not detected until $4 \mathrm{mbsf}$, thus methane produced within the upper anoxic sediments was either diffusing out of the sediment, being consumed in situ, or a combination of both. The presence of low rates of methane oxidation (Fig. 3) in this zone indicates that this process contributes to the removal of methane. Deeper in the sediment there is methane gas, methane formation, and methane oxidation. The increase in methanogenesis between 198 and 234 mbsf is consistent with an increase in methane gas concentrations (Fig. 3). Within the same zone, however, there is a considerable increase in methane oxidation, which may account for the peak in carbon dioxide also in this zone (Fig. 3). The BSR occurred at $225 \mathrm{mbsf}$ and above this was a hydrate layer to about $215 \mathrm{mbsf}$ (inferred from the low core temperatures between $-0.9^{\circ} \mathrm{C}$ and $-1.4^{\circ} \mathrm{C}$, Westbrook, Carson, Musgrave, et al., 1994; Fig. 4).

\section{Site 891}

\section{Bacterial populations}

Near-surface total bacterial counts at this site were the highest of the four sites at $1.52 \times 10^{9}$ cells $/ \mathrm{cm}^{3}$ (Fig. 5). Bacterial populations decreased rapidly with depth to $4.47 \times 10^{6} \mathrm{cells} / \mathrm{cm}^{3}$ at $8.81 \mathrm{mbsf}$, a factor of approximately $\times 340$. Because of very poor core recovery (Westbrook, Carson, Musgrave, et al., 1994), the first sample from Hole $891 \mathrm{~B}$ was at $65.5 \mathrm{mbsf}$. At this depth the bacterial population was $3.8 \times 10^{6} \mathrm{cells} / \mathrm{cm}^{3}$, a value not significantly different from the direct count obtained at 8.81 mbsf. Unexpectedly, between 65.5 and $465.3 \mathrm{mbsf}$ the bacterial population remained approximately constant (Fig. 5), ranging between $2.68 \times 10^{6}$ and $1.69 \times 10^{7} \mathrm{cells} / \mathrm{cm}^{3}$. Overall dividing cell numbers were relatively constant at approximately $13.5 \%$ of the direct count (Fig. 5), except between 1 and 4 mbsf, when dividing cell counts decreased significantly $(P<0.05)$ to $3.6 \%$ of the direct count. 
A

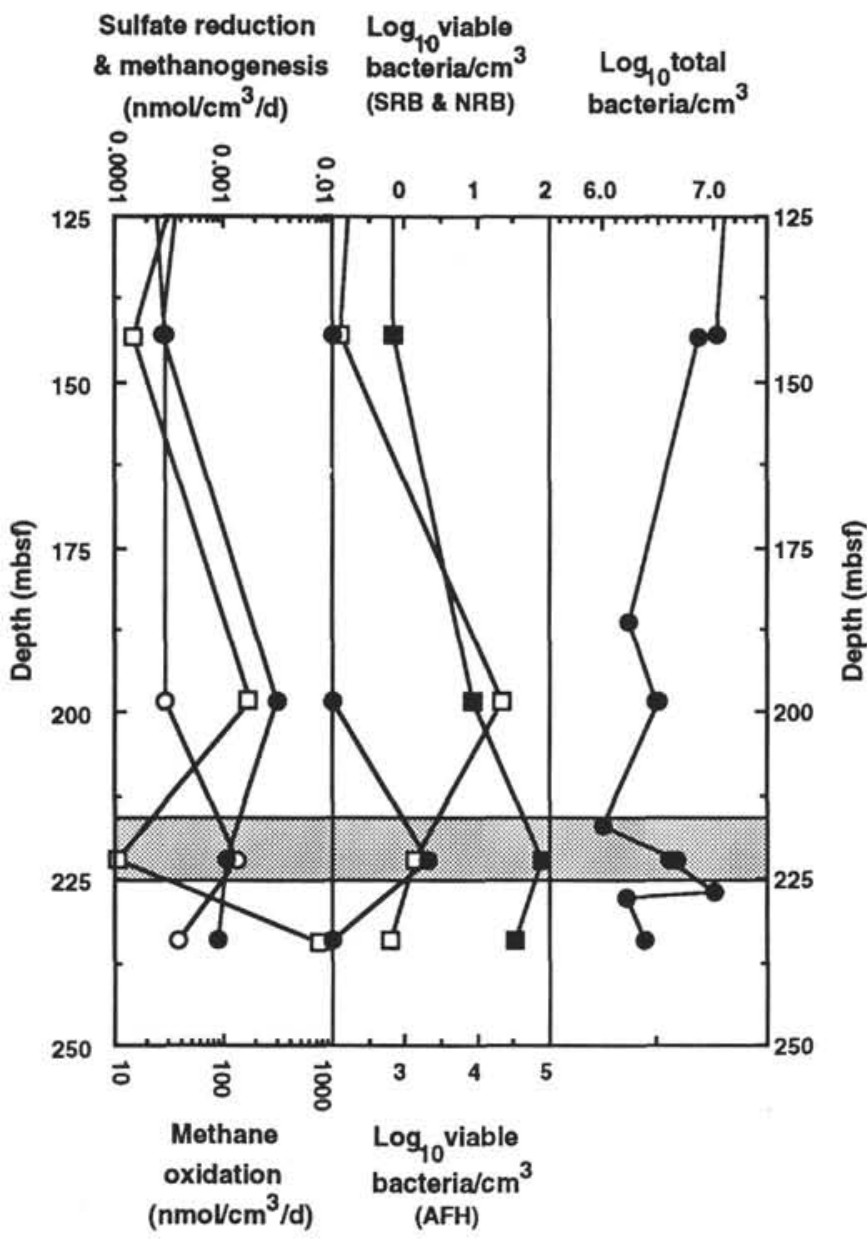

Figure 4. Holes $889 \mathrm{~A}$ and $890 \mathrm{~B}$ bacterial and geochemical depth distributions near the discrete hydrate zone. A. Bacterial activity rates of sulfate reduction (closed circles), methanogenesis (open squares), methane oxidation (open circles). B. Most Probable Numbers of viable sulfate-reducing (closed circles), nitrate-reducing (closed squares), heterotrophic (open squares) bacteria. C. Direct bacterial count (closed circles). The horizontal shaded area at depth $\sim 225$ mbsf indicates the zone where the presence of hydrate was inferred.

Viable bacterial populations follow a very similar distribution to the total bacterial population, with a rapid decrease in numbers at the near surface and a minimum reached between 1 and 2 mbsf for all three groups (Fig. 5). This coincides with a minimum in the dividing cell population and a minimum in the dividing cell to total population ratio (Fig. 5). Fermentative and sulfate-reducing bacteria (SRB) were both present at high concentrations at the sediment near-surface $(5.08$ $\times 10^{4}$ and $7.43 \times 10^{5} / \mathrm{cm}^{3}$, respectively). SRB decreased most rapidly and were not detected below $1.2 \mathrm{mbsf}$ (Fig. 5). Fermentative heterotrophs, however, decreased much less rapidly to a local minimum at $1.7 \mathrm{mbsf}$ and then remained relatively constant with depth. Nitratereducing bacteria were present only in low numbers with a maximum of $4.4 \times 10^{1} / \mathrm{cm}^{3}$ at the near-surface, which rapidly decreased to a minimum at 1.2 mbsf and were undetectable below $200 \mathrm{mbsf}$.

\section{Bacterial activity}

Sulfate reduction dominated the upper $1 \mathrm{~m}$ at this site, with a rate of $34.8 \mathrm{nmol} / \mathrm{cm}^{3} / \mathrm{d}$ (Fig. 5). This rapidly decreased to $0.013 \mathrm{nmol} /$ $\mathrm{cm}^{3} / \mathrm{d}$ at $1.2 \mathrm{mbsf}$ and then gradually increased to $0.059 \mathrm{nmol} / \mathrm{cm}^{3} / \mathrm{d}$ by $6.7 \mathrm{mbsf}$. The sulfate reduction rate correlated significantly with both the interstitial sulfate concentrations $(R=0.85 ; n=6 ; P<0.05)$ and the viable SRB population $(R=0.99 ; n=6 ; P<0.002)$. In the lower part of the hole, the sulfate reduction rate at $163 \mathrm{mbsf}$ was comparable with the $<1$ mbsf rate; however, below this there was a rapid decrease in activity, and no sulfate reduction was detected at either 288 or 367 mbsf.

Methanogenesis rates were low and always below that of sulfate reduction. Maximum rates at the near-surface $\left(0.0048 \mathrm{nmol} / \mathrm{cm}^{3} / \mathrm{d}\right)$ rapidly decreased to a minimum of $0.001 \mathrm{nmol} / \mathrm{cm}^{3} / \mathrm{d}$ between 1.8 and $3.7 \mathrm{mbsf}$, before increasing to $0.003 \mathrm{nmol} / \mathrm{cm}^{3} / \mathrm{d}$ at $6.8 \mathrm{mbsf}$ (Fig. 5). In Hole $891 \mathrm{~B}$ measured rates were considerably lower, averaging $0.0004 \mathrm{nmol} / \mathrm{cm}^{3} / \mathrm{d}$.

Methane oxidation rates again reflect an inverse profile to that of other activity measurements, with activity increasing in deeper sediments. The near-surface rate of $0.006 \mathrm{nmol} / \mathrm{cm}^{3} / \mathrm{d}$ gradually decreases to a minimum of $0.002 \mathrm{nmol} / \mathrm{cm}^{3} / \mathrm{d}$ at $1.2 \mathrm{mbsf}$, before increasing to $0.022 \mathrm{nmol} / \mathrm{cm}^{3} / \mathrm{d}$ at $6.7 \mathrm{mbsf}$ (Fig. 5). In Hole 891B, the measured rate at $163 \mathrm{mbsf}\left(0.023 \mathrm{nmol} / \mathrm{cm}^{3} / \mathrm{d}\right)$ is similar to that at $6.7 \mathrm{mbsf}$; however, with increasing depth there is a greater than three orders of magnitude increase to a maximum of $76.9 \mathrm{nmol} / \mathrm{cm}^{3} / \mathrm{d}$ at $288 \mathrm{mbsf}$, which is followed by a decrease to $21.9 \mathrm{nmol} / \mathrm{cm}^{3} / \mathrm{d}$ at $367 \mathrm{mbsf}$.

\section{Geochemistry}

Interpretation of the geochemistry of Site 891 is complicated by the fact that major differences in many of the inorganic species measured at this site indicate that Holes 891A and 891B are geochemically dissimilar (Westbrook, Carson, Musgrave, et al., 1994). Hence the two holes are reported separately. Rapid removal of sulfate in the top $7 \mathrm{~m}$ of $891 \mathrm{~A}$ is consistent with the high sulfate reduction rates (Fig. 5). As with Site $889 / 890$, there appears to be a negative relationship between the sulfate reduction rate and the rate of sulfide (TRIS) accumulation, particularly in the top $1 \mathrm{~m}$, indicating that near-surface sulfide is being oxidized. In Hole $891 \mathrm{~B}$ sulfate is present in high concentrations ( $>20 \mathrm{mmol} / \mathrm{L}$ ) to below $181 \mathrm{mbsf}$, then decreases rapidly to less than $0.5 \mathrm{mmol} / \mathrm{L}$ by $238 \mathrm{mbsf}$. At these depths the sulfate reduction rate is positively correlated with the sulfide accumulation rate $(R=0.95 ; n=4 ; P<0.05)$.

Despite the presence of methanogenic activity in the top $10 \mathrm{~m}$ of 891A (Fig. 5), methane was not detected, indicating diffusion out of the sediment or in situ consumption. Rates of methane oxidation that are considerably higher than those of methanogenesis (Fig. 5) indicates the potential for in situ removal of methane. In Hole 891B, the presence of high levels of methane coincides with the methanogenesis rate, although the two profiles are not entirely congruent (Fig. 5). Increases in methane below $250 \mathrm{mbsf}$ may be due to thermogenic input from deeper, more mature, sediments detected at several horizons between 314 and 410 mbsf (Westbrook, Carson, Musgrave, et al., 1994).

Carbon dioxide concentrations in 891B are low $(<6000 \mathrm{ppmv})$ to 239 mbsf and then rapidly increase to peak at 94,800 ppmv at 314 mbsf (Fig. 5). The carbon dioxide profile significantly correlates with the methane oxidation rate $(R=0.95 ; n=4 ; P<0.05)$. As the peaks of elevated carbon dioxide levels below $250 \mathrm{mbsf}$ also coincide with the presence of higher hydrocarbons, and hence some thermogenic input (Westbrook, Carson, Musgrave, et al., 1994), it may be that a portion of this carbon dioxide is not indigenous.

\section{Site 892}

\section{Bacterial populations}

Only direct bacterial counts were obtained at this site. Near-surface bacterial populations were lower than at the other three sites, at $2.19 \times 10^{7} / \mathrm{cm}^{3}$ (Fig. 6), despite organic carbon concentrations being the highest (1.18\%; Table 2$)$ at this site. Bacterial populations remained surprisingly constant with depth until approximately $30 \mathrm{mbsf}$ when there is a highly significant $(t=12.55 ;$ d.f. $=4 ; P<<0.0005)$ increase in the bacterial population from $3.8 \times 10^{6} / \mathrm{cm}^{3}$ to $1.4 \times$ $10^{8} / \mathrm{cm}^{3}$. The distribution of dividing cells was very similar, although 


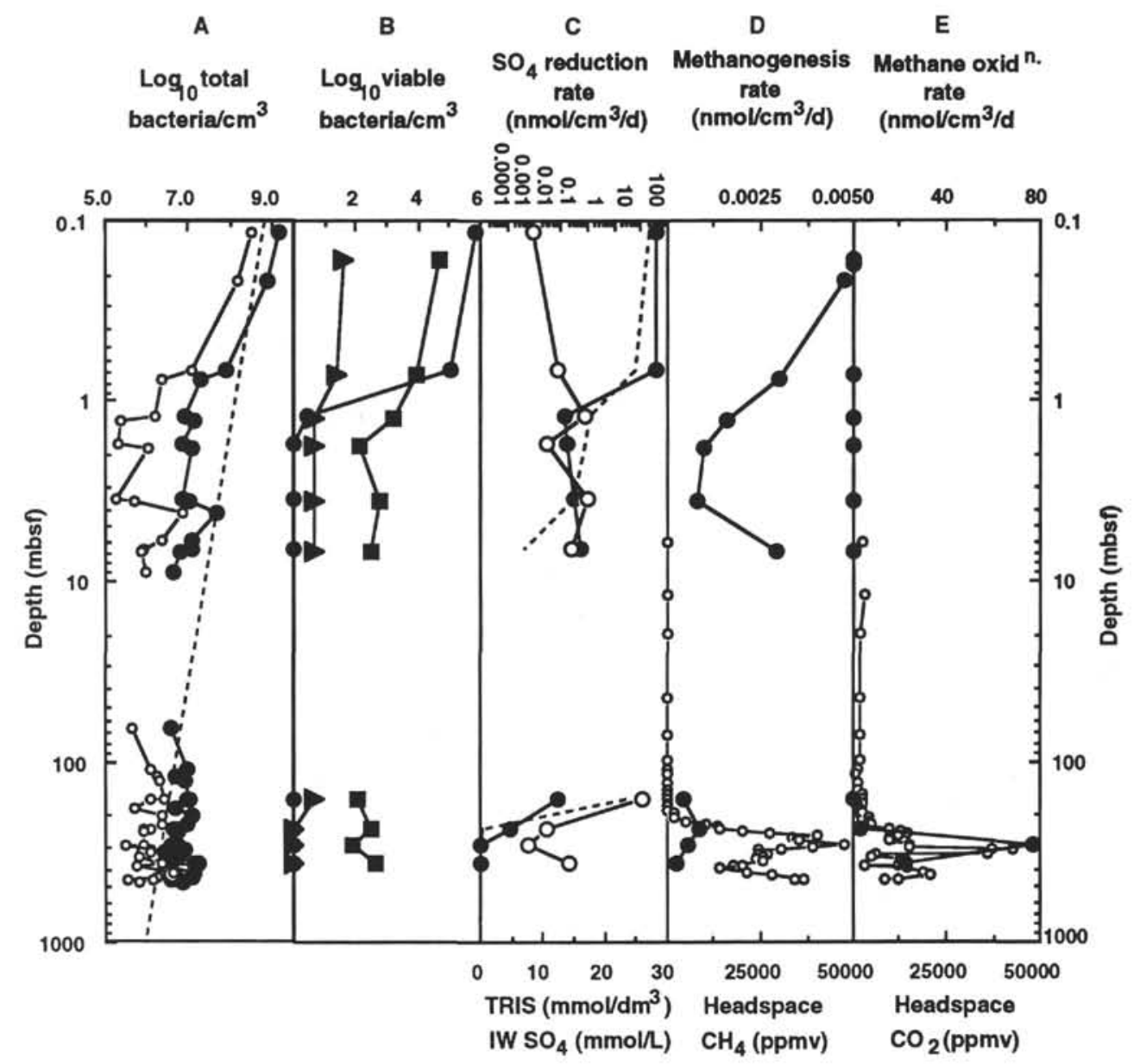

Figure 5. Holes 891A and 891B bacterial and geochemical depth distributions. A. total bacteria (closed circles), and dividing/divided cell numbers (open circles). The slanting heavy dashed line is a general regression line of bacterial numbers vs. depth derived from other Pacific sites (Parkes et al., 1994). B. Sulfatereducing bacteria (closed circles), fermentative heterotrophs (closed squares), and nitrate-reducing bacteria (closed triangles). C. Potential bacterial sulfate reduction rate (closed circles), TRIS (open circles), and pore-water sulfate (dashed line). D. Potential bacterial methanogenesis rate (closed circles), and headspace methane (smoothed using a 3-point moving average, open circles). E. Potential bacterial methane oxidation rate (closed circles) and headspace carbon dioxide (smoothed using a 3-point moving average, open circles).

their concentration was much less than the total bacterial population averaging $4.4 \%$ of the direct count.

A sediment volume was estimated of the contaminating sediment in the hydrate samples using the dry weights of our samples, sediment grain density, and sediment porosity data (Westbrook, Carson, Musgrave, et al., 1994). Comparison of direct bacterial counts, per unit volume of sediment, between these samples and bacterial populations on sediment samples from the same depth, but containing no hydrate, showed no significant difference.

\section{Geochemistry}

Very high concentrations of hydrogen sulfide were present in the expansion voids of cores in approximately the top $20 \mathrm{~m}(>10,000$ ppmv), coinciding with an active sulfate-reducing zone (sulfate removed by $20 \mathrm{mbsf}$ ), increasing methane gas concentrations and the presence of disseminated gas hydrates to about $20 \mathrm{~m}$ (Westbrook, Carson, Musgrave, et al., 1994).

\section{DISCUSSION}

Our previous research on the bacteriology of deep sediment layers in the Pacific Ocean demonstrated that bacterial depth profiles at five different sites were remarkably similar and the rate of decrease in bacterial populations was consistent from the sediment surface to in excess of 500 mbsf (Parkes et al., 1994). We have used this relationship to compare bacterial populations in these more complex Cascadia Margin sediments (Figs. 2A, 3A, and 5A), where intense tectonic activity results in expulsion of large quantities of fluids and volatile compounds through the sediments.

As expected in the control Site 888, bacterial populations and their depth distribution are very similar to the general trend in bacterial distributions (Fig. 2), and the bacterial population at $564 \mathrm{mbsf}$ $\left(1.13 \times 10^{7}\right)$ is the deepest bacterial population to be analyzed so far in marine sediments (Parkes et al., 1994). The same is true for the top 200 of Site $889 / 890$, but below this there is a discrete zone of increased bacterial populations associated with the methane hydrate zone between 215 and 225 mbsf (Fig. 4).

In Hole $891 \mathrm{~A}$, bacterial populations initially appear to follow the general trend of decrease; however, there is some evidence of persistently reduced numbers between 0.8 and $4.1 \mathrm{mbsf}$ (Fig. 5). This may be related to a relatively low organic carbon concentration in this zone $(0.43 \mathrm{wt} \%$ at $2.95 \mathrm{mbsf}$; Westbrook, Carson, Musgrave, et al., 1994). In contrast, at Hole $891 \mathrm{~B}$, all of the direct counts, with one exception, indicated bacterial populations approximately 3.6 times higher than expected (Fig. 5). Site 891 has a major thrust fault at 375 mbsf and also a number of anomalous compaction intervals produc- 


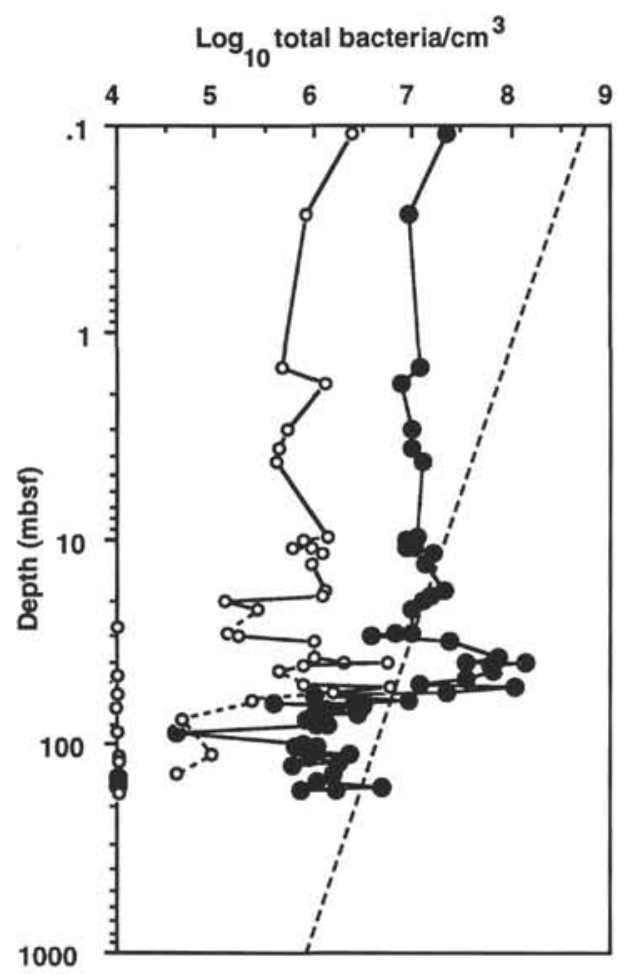

Figure 6. Holes $892 \mathrm{~A}$ and $892 \mathrm{D}$ depth distributions in bacterial populations. Total bacteria (closed circles), and dividing/divided cell numbers (open circles). Dashed lines between data points represent a count below the detection limit: these are given a nominal value of 4 and plotted on the vertical axis. The slanting heavy dashed line is a general regression line of bacterial numbers vs. depth derived from other Pacific sites (Parkes et al., 1994).

Table 2. Comparison of near-surface bacterial direct counts and sediment organic carbon concentrations.

\begin{tabular}{lcccc}
\hline \multicolumn{1}{c}{ ODP Leg } & Leg/Site & $\begin{array}{c}\text { Overlying } \\
\text { water depth } \\
(\mathrm{m})\end{array}$ & $\begin{array}{c}\text { Bacterial } \\
\text { direct count } \\
\left.\text { (cells/cm }{ }^{3}\right)\end{array}$ & $\begin{array}{c}\text { Organic } \\
\text { carbon** } \\
\text { (wt\%) }\end{array}$ \\
\hline Santa Barbara Basin & $146-893$ & 576.5 & $1.27 \times 10^{9}$ & 2.98 \\
Cascadia Margin & $146-892$ & 674.5 & $2.18 \times 10^{7}$ & 1.18 \\
Japan Sea & $128-798$ & 900.0 & $7.82 \times 10^{8}$ & 1.14 \\
Cascadia Margin & $146-890$ & 1326.3 & $6.95 \times 10^{8}$ & 0.64 \\
Juan de Fuca Ridge & $139-857$ & 2419.3 & $8.28 \times 10^{8}$ & 0.45 \\
Cascadia Margin & $146-888$ & 2516.3 & $5.32 \times 10^{8}$ & 0.56 \\
Cascadia Margin & $146-891$ & 2663.0 & $2.56 \times 10^{9}$ & 0.61 \\
Lau Basin & $135-834$ & 2702.9 & $6.12 \times 10^{8}$ & 0.26 \\
E. Equatorial Pacific & $138-851$ & 3760.3 & $2.08 \times 10^{8}$ & 0.05 \\
E. Equatorial Pacific & $138-851$ & 3773.0 & $7.71 \times 10^{7}$ & 0.05 \\
\hline
\end{tabular}

Notes: $* 0-1.5 \mathrm{mbsf} ;{ }^{* *}$ averaged over top $4 \mathrm{~m}$ of sediment. Overlying water depths and organic carbons Leg 146 (Kennet, Baldauf, et al., 1994; Westbrook, Carson, Musgrave, et al., 1994; R. Stein., pers. comm., 1994), Leg 139 (Davis, Mottl, Fisher, et al., 1992), Leg 138 (Mayer, Pisias, Janecek, et al,, 1992), Leg 135 (Parson, Hawkins, Allan, et al., 1992), and Leg 128 (Ingle, Suyehiro, von Breymann, et al., 1990).

ing discontinuities. These were all related to geochemical anomalies of both inorganic ion species and organic gases (Westbrook, Carson, Musgrave, et al., 1994), indicating that there was advective fluid flow at these discontinuities. The bacterial populations appear to be responding to this fluid flow at all depths below $290 \mathrm{mbsf}$, where bacterial numbers decrease at, or slightly below, the lithological discontinuity and increase (by an average of $\times 3.7$ ) around the geochemical anomalies (Fig. 7). The lack of any observable response in the bacterial population at the anomalies around 255-260 mbsf reflects the absence of samples in this region. Interestingly, at all four discontinuities between 250 and 440 mbsf, organic carbon concentra-

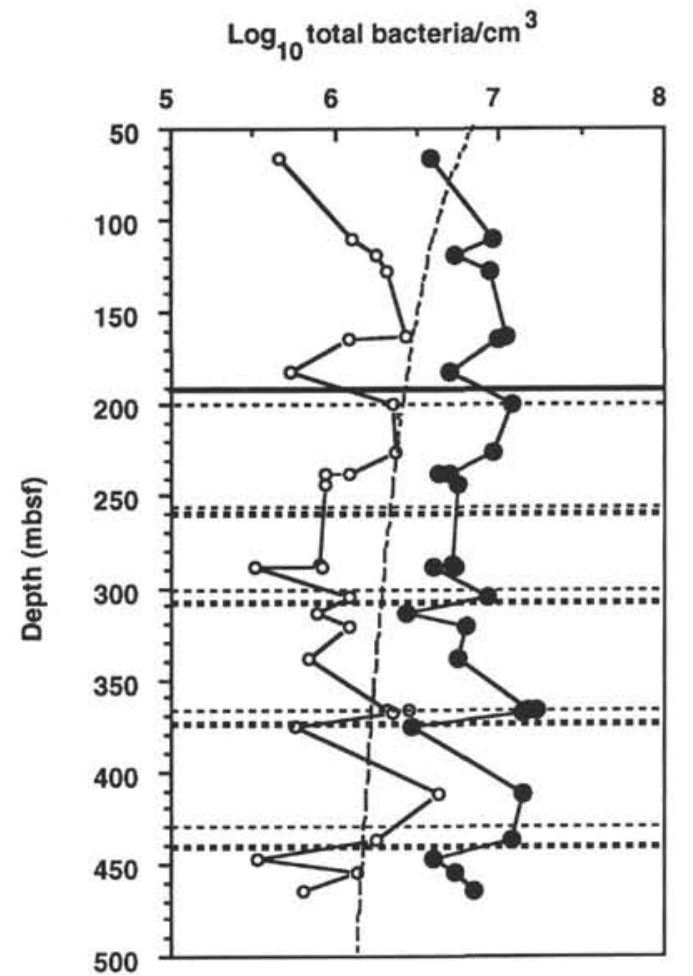

Figure 7. Holes 891A and 891B depth distributions in bacterial populations. Total bacteria (closed circles), and dividing/divided cell numbers (open circles). The curved dashed line is a general regression line of bacterial numbers vs. depth derived from other Pacific sites (Parkes et al., 1994). The heavy horizontal line represents a zone of carbonate cementation. Heavy horizontal dashed lines represent structural discontinuities and light horizontal dashed lines represent geochemical anomalies.

tions increased approximately $\times 3.5$, compared to those in adjacent sediments, from an average of 0.21 to $0.74 \mathrm{wt} \%$ (Westbrook, Carson, Musgrave, et al., 1994). A fifth geochemical anomaly occurred at 200 mbsf, also associated with a slightly elevated bacterial population (Fig. 7). This was immediately below a layer of carbonate cementation at 191 mbsf, which may have formed a barrier to fluid flow, thus separating this sediment into two hydrological systems (Westbrook, Carson, Musgrave, et al., 1994). The bacterial populations at the near-surface of Hole 891A were abnormally high $(\times 4.5)$ when compared to other Pacific Ocean sites of similar overlying water depth (Fig. 5; Table 2). Hole 891A was close to a site of active fluid venting associated with enhanced macro- and microbenthic communities (e.g., clams and bacterial mats) at the sediment surface. The presence nearby of a carbon-rich biological community and a supply of vent fluids, believed to originate from below $200 \mathrm{mbsf}$ (Westbrook, Carson, Musgrave, et al., 1994) may also be the cause of the elevated near-surface bacterial population and is consistent with the association of elevated bacterial populations $(\times 3.7)$ and fluid venting observed in the deeper layers (Fig. 7). The fluid profiles of Hole 891A and the shallow portion of Hole 891B were radically different despite only being separated by $30 \mathrm{~m}$ (Westbrook, Carson, Musgrave, et al., 1994), and so are the corresponding bacterial profiles (Fig. 5). Both sets of data emphasize the spatial heterogeneity of fluid flows at this accretionary site.

At Site 892, the bacterial populations in the top approximately 30 $\mathrm{m}$ are lower than the general bacterial regression line, with the deviation being most marked at the sediment surface (Fig. 6); the two shallowest direct counts at 0.11 and 0.27 mbsf being significantly $(P$ $<0.05)$ lower than expected. This 30 -m-section of the sediment coin- 
cides with the zone of disseminated hydrate and very high sulfide concentrations. Below this zone bacterial populations increase and are actually above the regression line. This increase coincides with an increase in organic carbon from 1.22 to $1.84 \mathrm{wt} \%$ (Westbrook, Carson, Musgrave, et al., 1994). The low near-surface bacterial population, however, cannot be explained by a low concentration of organic carbon, as this is higher at Site 892 than at the other three sites, which have near-surface bacterial populations that are significantly $(P<$ 0.05 ) greater $\left(\right.$ Site $888=5.32 \times 10^{8} / \mathrm{cm}^{3}$; Site $889 / 890=6.95 \times 10^{8} /$ $\mathrm{cm}^{3} ; 891=2.56 \times 10^{9} ;$ Site $\left.892=2.2 \times 10^{7} / \mathrm{cm}^{3}\right)$. Additionally, the near-surface bacterial population at Site 892 is lower than expected, on the basis of water depth and organic carbon concentrations at a range of other Pacific Ocean sites (Table 2). Another possibility for low near-surface bacterial populations might be that the organic carbon is resistant to bacterial degradation, but this seems very unlikely as there is active sulfate reduction and high methane gas concentrations within the same zone. As high levels of hydrogen sulfide are toxic even to bacteria (Brown et al., 1973; Postgate, 1984; van Gemerden, 1993), it is possible that the concentration of hydrogen sulfide within the top $30 \mathrm{~m}$ of sediment at Site 892 inhibited a proportion of the bacterial population. The disseminated hydrates within this zone may have held some of the hydrogen sulfide in the crystal lattice, thus preventing both its upward diffusion and subsequent oxidation or precipitation as iron sulfides. The dynamic nature of hydrates (Hyndman and Davis, 1992) would result in locally high concentrations of hydrogen sulfide in the sediment. Direct microscopic analysis of bacteria in hydrate samples indicated that, at this site, the hydrate did not have populations different from that which could be attributed to the sediment particles present with the hydrate sample. This may, however, be a reflection of the inhibitory sulfide concentrations at this site. There may be other reasons for the anomalously low near-surface bacterial populations but the presence of the hydrate appears to be an important and probably central factor.

Bacterial direct counts on samples from Holes 892A and D, which are approximately $33 \mathrm{~m}$ apart (Westbrook, Carson, Musgrave, et al., 1994), also provide evidence of spatially heterogeneous subsurface fluid flow at this site. The profiles for both holes were very similar to about $80 \mathrm{mbsf}$; however, below this depth there were zones where the bacterial population was much lower in Hole $892 \mathrm{~A}$ (Fig. 8), which were most obvious around $88 \mathrm{mbsf}$ and $138-145 \mathrm{mbsf}$. The zone $138-145$ mbsf is particularly interesting as bacterial populations were below our detection limit (see "Methods," this chapter), the first time this has occurred in non-hydrothermally heated sediments (Cragg and Parkes, 1994). Both of these depths in Hole 892A were associated with moderate to strong UV fluorescing material, reflecting the presence of thermally generated aromatic hydrocarbons (Westbrook, Carson, Musgrave, et al., 1994), some of which can be toxic to bacteria. Similar fluorescence was detected at 22 and 29.5 mbsf (Fig. 8); although the effect on the bacterial population is not obvious, there is a local minimum in the bacterial populations of both holes. In addition, any inhibitory effects of aromatic compounds on bacteria in the top 30 mbsf may be masked by the toxic effects of the very high sulfide concentration in this zone.

At the three other sites, a more detailed analysis of bacterial processes was conducted. In the control Site 888 , these are straightforward down to about $90 \mathrm{mbsf}$ and, as expected for a low organic carbon marine site, are dominated by sulfate reduction. Initial rates of sulfate reduction are high $\left(84.5 \mathrm{nmol} / \mathrm{cm}^{3} / \mathrm{d}\right)$ but rapidly decrease with depth as labile organic carbon is utilized. The low rates below $10 \mathrm{mbsf}$, however, are sufficient over the length of the core to remove dissolved sulfate and produce considerable amounts of reduced sulfide (Fig. 2).

Superimposed on this typical trend is a local depletion of sulfate between 87 and 113 mbsf, which coincides with peaks in both methane and carbon dioxide (Fig. 2). Bacterial populations and activities are also stimulated in this zone (Fig. 2), and their activity must maintain these steep gradients. Despite the limited microbiological data in

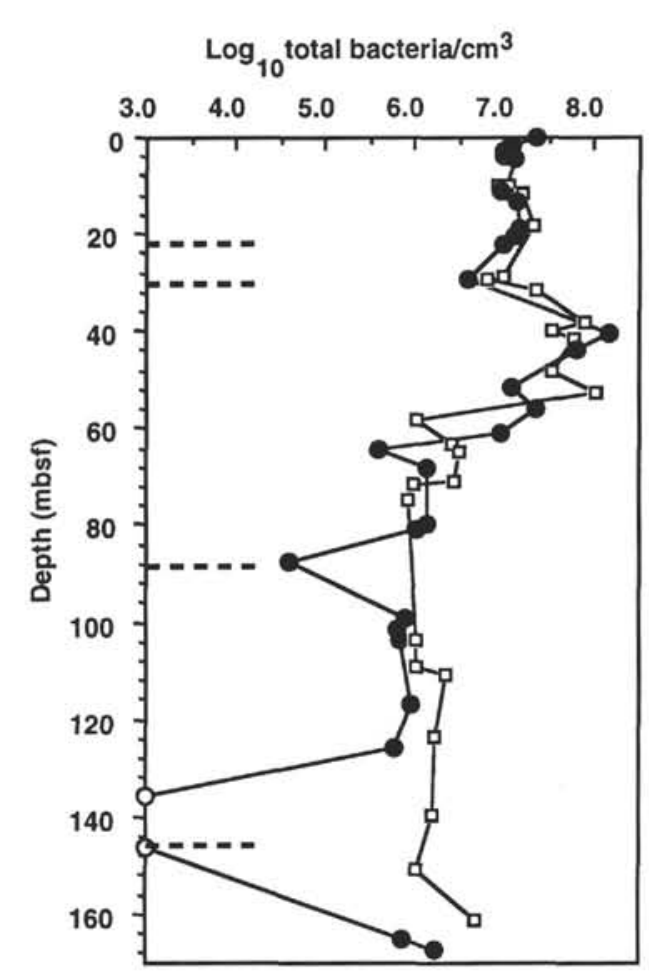

Figure 8. Site 892 depth distributions in bacterial populations. Total bacteria in Holes 892A (closed circles) and 892D (open squares). Dashed horizontal lines on the left of the graph indicate depths at which the presence of aromatic hydrocarbons were detected by UV fluorescence. Open circles on the $y$-axis represent counts below the detection limit.

this zone, they indicate a stimulation of bacterial activity caused by a zone of available organic carbon that is consistent with increases in alkalinity, ammonia, and phosphate (Westbrook et al., 1994). This is discussed by Cragg et al. (in press), and, although greater spatial resolution in the microbiological data is required for definitive conclusions concerning this geochemical anomaly, the microbiological results demonstrate the significant geochemical impact bacterial processes can make, even in deep sediments, and also the sensitivity and reliability of the microbiological techniques.

Below the zone of sulfate depletion methane concentrations increase, possibly due to a high-porosity and high permeability zone at 351 mbsf, providing a deep conduit for lateral gas transport into this site (Westbrook et al., 1994). This may account for the stimulation in methane oxidation in the deepest layers at this site and an increase in the bacterial population (Fig. 2), indicating that the site may have not been far enough away from the accretionary wedge to represent a true control.

In the top approximately $90 \mathrm{~m}$ of Site $889 / 890$, the distributions of bacterial populations and activities were broadly similar to those of the control site (Figs. 2 and 3). Methanogenesis and methane, however, increased within the first few meters in Site 889/890, where metal sulfides were present. This indicates that, near the surface, this site was probably highly reducing and hence, despite lower sulfate reduction rates than the control site, sulfate was removed within the top $10 \mathrm{~m}$. A major difference was the presence of the discrete hydrate layer above the BSR, between 215 and 225 mbsf (Fig. 4). Bacterial processes clearly respond to the geochemical changes within this zone (Cragg et al., in press). Methane oxidation increases by approximately a factor of five, sulfate-reducing bacteria that had been undetectable since $10 \mathrm{mbsf}$ were present, nitrate-reducing bacteria increase by a factor of two, and the total bacterial population by a factor of ten. In addition, sulfate-reduction and methanogenic rates, and 
fermentative heterotrophs are elevated just above, and methanogenesis just below, this zone.

The increase in bacterial populations, combined with the increase in methane oxidation rates, indicates that methane is being used effectively as an energy source within this zone. This may also account for the low measured rates of methanogenesis, as produced ${ }^{14} \mathrm{CH}_{4}$ would be rapidly re-oxidized to ${ }^{14} \mathrm{CO}_{2}$. Although sulfate-reducing bacteria, which have been implicated in anaerobic methane oxidation (Iversen and Jørgensen, 1985; Schulz et al., 1994), were stimulated in this zone, sulfate reduction was actually higher just above this zone. Sulfate reduction may, however, be limited (Winfrey and Zeikus, 1977) by the very low sulfate concentrations present (Fig. 3). The presence of any sulfate so deep in these anoxic sediments could be considered contamination from sea water during drilling (Westbrook et al., 1994), but anoxic sulfide oxidation could also produce sulfate (Fossing and Jørgensen, 1990), the supply of which would be enhanced by fluid flow in these sediments (Westbrook, Carson, Musgrave, et al., 1994). Anoxic sulfide oxidation in deep sediments (4-8 mbsf) has recently been considered (Schulz et al., 1994) as the only possible explanation for a build-up of sulfide without a change in pore water sulfate, a situation observed also in these sediments (Fig. $3)$. Irrespective of the sulfate concentrations, the production of radiolabeled ${ }^{35} \mathrm{~S}$-sulfide during radiotracer incubations demonstrates the presence of a zone of potential sulfate reduction within and close to the hydrate zone (Fig. 3).

There remains the possibility that because of sulfate limitation in situ these bacteria may be using other respiratory compounds such as iron (Coleman et al., 1993; Lovley et al., 1993). Interestingly, the stimulation of bacteria capable of reducing nitrate also correlates with the stimulation of methane oxidation in the hydrate zone (Fig. 4 ), which indicates that bacteria able to use electron acceptors other than, or in addition to, sulfate may also be involved in anaerobic methane oxidation.

These ambiguities regarding the electron acceptor(s) for anaerobic methane oxidation may, in part, explain why anaerobic bacteria able to catalyze this process have yet to be isolated; however, our data contributes to the large number of publications demonstrating that it is an important environmental process (Kosiur and Warford, 1979; Zehnder and Brock, 1980; Alperin and Reeburgh, 1985; Iversen and Jørgensen, 1985; Oremland, 1988; Suess and Whiticar, 1989; Jørgensen et al., 1990; Helgeson et al., 1991; King, 1992; Masuzawa et al., 1992; Schulz et al., 1994).

Rates of methane oxidation at control Site 888 ranged from 0.002 to $0.705 \mathrm{nmol} / \mathrm{cm}^{3} / \mathrm{d}$, or 0.002 to $0.033 \mathrm{nmol} / \mathrm{cm}^{3} / \mathrm{d}$, excluding the deepest sediment, which was probably influenced by deep methane flux. These low rates are similar to those measured by Iversen and Jørgensen (1985) for shallow water marine sediments $(0.002-0.1$ $\mathrm{nmol} / \mathrm{cm}^{3} / \mathrm{d}$ ). By contrast, at the venting site (891), which had higher concentrations of methane, there were markedly increased rates of methane oxidation $\left(0.002-76.9 \mathrm{nmol} / \mathrm{cm}^{3} / \mathrm{d}\right)$. Maximum rates of methane oxidation, however, were at the diffuse-flow hydrate site $(889 / 890)$, which had even higher concentrations of biogenic methane and probably a deep source of thermogenic hydrocarbons (Westbrook, Carson, Musgrave, et al., 1994), and had methane oxidation rates ranging from 0.124 to $134.5 \mathrm{nmol} / \mathrm{cm}^{3} / \mathrm{d}$. As the amount of allochthonous methane increases because of active fluid flow through the sediments at these three sites, so maximum rates of methane oxidation increase (Table 3) to well in excess of those in shallow-water marine sediments (Iversen and Jørgensen, 1985). At the same time, near-surface sulfate reduction rates decrease and, hence, so does the relative contribution of organic matter to driving bacterial processes and geochemistry. The effect is that at both the fluid venting site (Site 891 ) and the diffuse venting hydrate site (Site 889/890), maximum rates of bacterial activity occur below 200 mbsf (Table 3), fueled by a deep source of gases and fluids. This is in marked contrast to the normal situation of maximum near-surface rates of bacterial activity as in the control site (Site 888). At Site 889/890, the maximum oxidation rates in the hydrate zone were approximately nine times higher than the average rate at other depths and coincide with a large, sixteen-fold increase in carbon dioxide (Fig. 3). This represents a considerable potential for biological methane utilization in the hydrate zone, which is consistent with the significant increase in the bacterial population within this zone (Fig. 4). The electron acceptors for methane oxidation at these sites remain unclear, but they may, in part, also be provided by the fluid flux into accretionary sediments, thus enabling high rates of oxidation to be established and maintained.

\section{SUMMARY}

In subduction zone sediments the geological processes resulting in expulsion of fluids and gases cause the elevated subsurface bacterial populations and activities, as a deep bacterial biosphere responds effectively to a new energy source. The formation of discrete gas hydrate zones also results in elevated bacterial activity and methane cycling, but, near the surface, disseminated hydrate appears to be associated with a reduction in bacterial populations, possibly caused by the extremely high concentrations of hydrogen sulfide. Advecting fluids may also supply electron acceptors to maintain elevated deep bacterial activity, but, on a local scale, some components may be toxic (e.g., aromatic hydrocarbons) to a portion of the total bacterial population. Variation in bacterial profiles between cores, only a few meters apart at the same site (at Sites 891 and 892), closely reflect spatial heterogeneity in geochemistry and fluid expulsion in these accretionary sediments and demonstrate that bacterial processes are a sensitive index for the deep fluid and gas venting that may drive many of the geochemical changes.

\section{ACKNOWLEDGMENTS}

We thank ODP for allowing us to obtain samples on Leg 146 and the technical staff, in particular, on this Leg for helping us to collect the samples. We acknowledge S.J. Bale, P. Wellsbury, J. Getliff, K. Goodman, J. Kelly, R. Allen, T. Woodward, and M. Prideaux for their invaluable assistance during initial sediment handling in the laboratory. This work was funded by Natural Environment Research Council (U.K.) grant GST/02/683 .

Table 3. Comparison of organic carbon concentrations and maximum bacterial activity rates between the near-surface and sub-200 mbsf at three Leg 146 sites.

\begin{tabular}{lcccccc}
\hline Depth: & \multicolumn{3}{c}{ Near-surface } & & \multicolumn{2}{c}{ Sub-200 mbsf } \\
\cline { 2 - 3 } Parameter: & $\begin{array}{c}\text { Organic carbon } \\
(\mathrm{wt} \%)\end{array}$ & $\begin{array}{c}\text { Sulfate } \\
\left(\mathrm{nmol} / \mathrm{cm}^{3} / \mathrm{d}\right)\end{array}$ & $\begin{array}{c}\text { Methanogenesis } \\
\left(\mathrm{nmol} / \mathrm{cm}^{3} / \mathrm{d}\right)\end{array}$ & & $\begin{array}{c}\text { Methanogenesis } \\
\left(\mathrm{nmol} / \mathrm{cm}^{3} / \mathrm{d}\right)\end{array}$ & $\begin{array}{c}\text { Methane oxidation } \\
\left(\mathrm{nmol} / \mathrm{cm}^{3} / \mathrm{d}\right)\end{array}$ \\
\hline Site 888 & 0.56 & 84.50 & 0.0071 & & 0.0029 & 0.71 \\
Site 891 & 0.61 & 34.96 & 0.0048 & & 0.00087 & 76.91 \\
Site 889/890 & 0.64 & 6.85 & 0.027 & & 0.0077 & 134.54 \\
\hline
\end{tabular}




\section{REFERENCES}

Alperin, M.J., and Reeburgh, W.S., 1985. Inhibition experiments on anaerobic methane oxidation. Appl. Environ. Microbiol., 50:940-945.

Bekins, B.A., and Dreiss, S.J., 1992. A simplified analysis of parameters controlling dewatering in accretionary prisms. Earth Planet. Sci. Lett., 109:275-287.

Brown, D.E., Groves, G.R., and Miller, J.D.A., 1973. pH and Eh control of cultures of sulfate-reducing bacteria. J. Appl. Chem. Biotechnol., 23:141149.

Carson, B., Suess, E., and Strasser, J.C., 1990. Fluid flow and mass flux determinations at vent sites on the Cascadia margin accretionary prism. $J$. Geophys. Res., 95:8891-8897.

Carson, B., Holmes, M.L., Umstattd, K., Strasser, J., and Johnson, H.P., 1991. Fluid expulsion from the Cascadia accretionary prism: evidence from porosity distribution, direct measurements, and GLORIA imagery. Philos. Trans. R. Soc. London A, 335:331-340.

Coleman, M.L., Hedrick, D.B., Lovley, D.R., White, D.C., and Pye, K., 1993. Reduction of Fe(III) in sediments by sulfate-reducing bacteria. Nature, 361:436-438.

Colwell, R.R., 1979. Enumeration of specific populations by the Most-Probable-Number (MPN) method. In Costerton, J.W., and Colwell, R.R. (Eds.), Native Aquatic Bacteria: Enumeration, Activity, and Ecology: Philadelphia (ASTM), ASTM STP 695:56-61.

Cragg, B.A., 1994. Bacterial profiles in deep sediment layers from the Lau Basin (Site 834). In Hawkins, J., Parson, L., Allan, J., et al., Proc. ODP, Sci. Results, 135: College Station, TX (Ocean Drilling Program), 147150 .

Cragg, B.A., Bale, S.J., and Parkes, R.J., 1992a. A novel method for the transport and long-term storage of cultures and samples in an anaerobic atmosphere. Lett. Appl. Microbiol., 15:125-128.

Cragg, B.A., Harvey, S.M., Fry, J.C., Herbert, R.A., and Parkes, R.J., 1992b. Bacterial biomass and activity in the deep sediment layers of the Japan Sea, Hole 798B. In Pisciotto, K.A., Ingle, J.C., Jr., von Breymann, M.T., Barron, J., et al., Proc. ODP, Sci. Results., $127 / 128$ (Pt. 1): College Station, TX (Ocean Drilling Program), 761-776.

Cragg, B.A., and Parkes, R.J., 1994. Bacterial profiles in hydrothermally active deep sediment layers from Middle Valley (NE Pacific), Sites 857 and 858. In Mottl, M.J., Davis, E.E., Fisher, A.T., and Slack, J.F. (Eds.), Proc. ODP, Sci. Results, 139: College Station, TX (Ocean Drilling Program), 509-516.

Cragg, B.A., Parkes, R.J., Fry, J.C., Herbert, R.A., Wimpenny, J.W.T., and Getliff, J.M., 1990. Bacterial biomass and activity profiles within deep sediment layers. In Suess, E., von Huene, R., et al., Proc. ODP, Sci. Results, 112: College Station, TX (Ocean Drilling Program), 607-619.

Cragg, B.A., Parkes, R.J., Fry, J.C., Weightman, A.J., Rochelle, P.A., and Maxwell, J.R., in press. Bacterial populations and processes in sediments containing gas hydrates (ODP Leg 146: Cascadia Margin), Earth Planet. Sci. Lett.

Davis, E.E., Hyndman, R.D., and Villinger, H., 1990. Rates of fluid expulsion across the Northern Cascadia accretionary prism: constraints from new heat flow and multichannel seismic reflection data. J. Geophys. Res., 95:8869-8889.

Davis, E.E., Mottl, M.J., Fisher, A.T., et al., 1992. Proc. ODP, Init. Repts., 139: College Station, TX (Ocean Drilling Program).

Fossing, H., and Jørgensen, B.B., 1989. Measurement of bacterial sulfate reduction in sediments: evaluation of a single-step chromium reduction method. Biogeochemistry, 8:205-222.

, 1990. Oxidation and reduction of radiolabeled inorganic sulphur compounds in an estuarine sediment, Kysing Fjord, Denmark. Geochim. Cosmochim. Acta, 54:2731-2742.

Fry, J.C., 1988. Determination of biomass. In Austin, B. (Ed.), Methods in Aquatic Bacteriology: Chichester (Wiley), 27-72.

Goulder, R., 1977. Attached and free bacteria in an estuary with abundant suspended solids. J. Appl. Bacteriol., 43:399-405.

Helgeson, H.C., Knox, A.M., and Everett, L.S., 1991. Petroleum, oil field brines, and authigenic mineral assemblages: are they in metastable equilibrium in hydrocarbon reservoirs? Abstr. 15th Eur. Assoc. Org. Geochem., 39

Hurley, M.A., and Roscoe, M.E., 1983. Automated statistical analysis of microbial enumeration by dilution series. J. Appl. Bacteriol., 55:159164.
Hyndman, R.D., and Davis, E.E., 1992. A mechanism for the formation of methane hydrate and seafloor bottom-simulating reflectors by vertical fluid expulsion. J. Geophys. Res., 97:7025-7041.

Ingle, J.C., Jr., Suyehiro, K., von Breymann, M.T., et al., 1990. Proc. ODP, Init. Repts., 128: College Station, TX (Ocean Drilling Program).

Iversen, N., and Jørgensen, B.B., 1985. Anaerobic methane oxidation rates at the sulfate-methane transition in marine sediments from Kattegat and Skagerrak (Denmark). Limnol. Oceanogr., 30:944-955.

Jørgensen, B.B., Bang, M., Blackburn, T.H., 1990. Anaerobic mineralization in marine sediments from the Baltic Sea-North Sea transition. Mar. Ecol. Prog. Ser., 59:39-54.

Kennett, J.P., Baldauf, J.G., et al., 1994. Proc. ODP, Init. Repts., 146 (Pt. 2): College Station, TX (Ocean Drilling Program).

King, G.M., 1992. Ecological aspects of methane oxidation, a key determinant of global methane dynamics. Adv. Microb. Ecol., 12:431-468.

Kosiur, D.R., and Warford, A.L., 1979. Methane production and oxidation in Santa Barbara Basin sediments. Estuarine Coastal Marine Sci., 8:379 385.

Kulm, L.D., and Suess, E., 1990. Relationship between carbonate deposits and fluid venting: Oregon accretionary prism. J. Geophys. Res., 95:8899-8915.

Kulm, L.D., Suess, E., Moore, J.C., Carson, B., Lewis, B.T., Ritger, S.D., Kadko, D.C., Thornburg, T.M., Embley, R.W., Rugh, W.D., Massoth, G.J., Langseth, M.G., Cochrane, G.R., and Scamman, R.L., 1986. Oregon subduction zone: venting, fauna, and carbonates. Science, 231:561566.

Lewis, B.T.R., and Cochrane, G.R., 1990. Relationship between the location of chemosynthetic benthic communities and geologic structure on the Cascadia subduction zone. J. Geophys. Res., 95:8783-8793.

Linke, P., Suess, E., Torres, M., Martens, V., Rugh, W.D., Ziebis, W., and Kulm, L.D., 1994. In situ measurement of fluid flow from cold seeps at active continental margins. Deep-Sea Res., 41:721-739.

Lovley, D.R., Roden, E.E., Phillips, E.J.P., and Woodward, J.C., 1993. Enzymatic iron and uranium reduction by sulfate-reducing bacteria. Mar. Geol., 113:41-53.

Masuzawa, T., Handa, N., Kitagawa, H., and Kusakabe, M., 1992. Sulfate reduction using methane in sediments beneath a bathyal "cold seep" giant clam community off Hatsushima Island, Sagami Bay, Japan. Earth Planet. Sci. Lett., 110:39-50.

Mayer, L., Pisias, N., Janecek, T., et al., 1992. Proc. ODP. Init. Repts., 138 (Pt. 1): College Station, TX (Ocean Drilling Program).

Moore, J.C., Brown, K.M., Horath, F., Cochrane, G., MacKay, M., and Moore, G., 1991. Plumbing accretionary prisms: effects of permeability variations. Philos. Trans. R. Soc. London A, 335:275-288.

Oremland, R.S., 1988. Biogeochemistry of methanogenic bacteria. In Zehnder, A.J.B. (Ed.), Biology of Anaerobic Microorganisms: New York (Wiley), 641-705.

Parkes, R.J., Cragg, B.A., Bale S.J., and Fry, J.C., in press. A combined ecological and physiological approach to studying sulfate reduction within deep marine sediment layers. J. Microbiol. Methods.

Parkes, R.J., Cragg, B.A., Bale, S.J., Getliff, J.M., Goodman, K., Rochelle, P.A., Fry, J.C., Weightman, A.J., and Harvey, S.M., 1994. Deep bacterial biosphere in Pacific Ocean sediments. Nature, 371:410-413.

Parkes, R.J., Cragg, B.A., Fry, J.C., Herbert, R.A., and Wimpenny, J.W.T., 1990. Bacterial biomass and activity in deep sediment layers from the Peru margin. Philos. Trans. R. Soc. London A, 331:139-153.

Parson, L., Hawkins, J., Allan, J., et al., 1992. Proc. ODP, Init. Repts., 135: College Station, TX (Ocean Drilling Program).

Postgate, J.R., 1984. The Sulphate-reducing Bacteria (2nd ed.): Cambridge (Cambridge Univ. Press).

Schulz, H.D., Dahmke, A., Schinzel, U., Wallman, K., and Zabel, M., 1994. Early diagenetic processes, fluxes, and reaction rates in sediments of the South Atlantic. Geochim. Cosmochim. Acta, 58:2041-2060.

Suess, E., Carson, B., Ritger, S., Moore, J.C., Jones, M., Kulm, L.D., and Cochrane, G., 1985. Biological communities at vent sites along the subduction zones off Oregon. In Jones, M.L. (Ed.), The Hydrothermal Vents of the Eastern Pacific: An Overview. Bull. Biol. Soc. Wash., 6:475-484.

Suess, E., and Whiticar, M.J., 1989. Methane-derived $\mathrm{CO}_{2}$ in pore fluids expelled from the Oregon subduction zone. Palaeogeogr., Palaeoclimatol., Palaeoecol., 71:119-136.

van Gemerden, H., 1993. Microbial mats: a joint venture. Mar. Geol., 113:3 25 . 
Westbrook, G.K., Carson, B., Musgrave, R.J., et al., 1994. Proc, ODP, Init. Repts., 146 (Pt. 1): College Station, TX (Ocean Drilling Program).

Winfrey, M.R., and Zeikus, J.G., 1977. Effect of sulfate on carbon and electron flow during microbial methanogenesis in freshwater sediments. Appl. Environ. Microbiol., 33:275-281.
Zehnder, A.J.B., and Brock, T.D., 1980. Anaerobic methane oxidation: occurrence and ecology. Appl. Environ. Microbiol., 39:194-204.

Date of initial receipt: 5 December 1994

Date of acceptance: 29 May 1995

Ms 146SR-241 